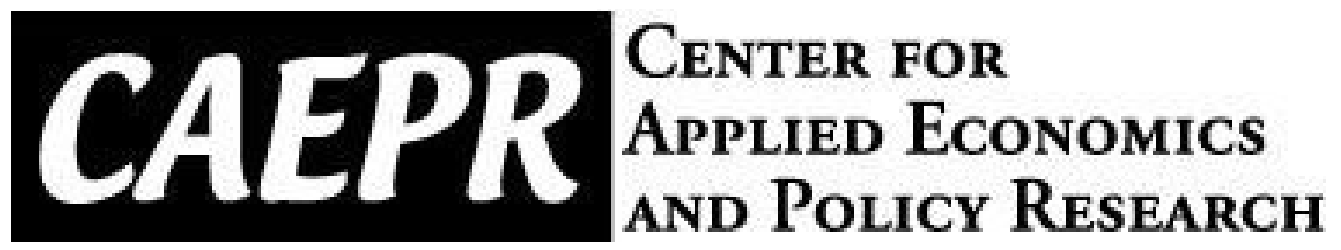

CAEPR Working Paper

\#2015-०12

\title{
Debt Dilution and Sovereign Default Risk
}

\author{
Juan Carlos Hatchondo \\ Indiana University \\ Leonardo Martinez \\ IMF \\ C'esar Sosa-Padilla \\ McMaster University
}

June 30, 2015

This paper can be downloaded without charge from the Social Science Research Network electronic library at http://papers.ssm.com/sol3/papers.cfm?abstract id=2625239

The Center for Applied Economics and Policy Research resides in the Department of Economics at Indiana University Bloomington. CAEPR can be found on the Internet at:

http://www.indiana.edu/ caepr. CAEPR can be reached via email at caepr@indiana.edu or via phone at 812-855-4050.

(C)2015 by Juan Carlos Hatchondo, Leonardo Martinez and C'esar Sosa-Padilla. All rights reserved. Short sections of text, not to exceed two paragraphs, may be quoted without explicit permission provided that full credit, including (C) notice, is given to the source. 


\title{
Debt Dilution and Sovereign Default Risk
}

\author{
Juan Carlos Hatchondo \\ Indiana University
}

Leonardo Martinez

International Monetary Fund

César Sosa-Padilla

McMaster University

For comments and suggestions, we thank Monika Piazzesi and four anonymous referees. We thank Christoph Trebesch and Mark Wright for sharing their data with us. We also thank Fernando Alvarez, Luis Brandao-Marques, Fernando Broner, Satyajit Chatterjee, Luca Dedola, Pablo D’Erasmo, Bora Durdu, Laura Grigolon, Maxim Ivanov, Amartya Lahiri, Enrique Mendoza, Andres Neumeyer, Dirk Niepelt, Jorge Roldos, Guido Sandleris, Diego Saravia, and seminar participants at the University of Virginia, the Board of Governors, the Atlanta, Minneapolis, Philadelphia, and Richmond Feds, the Universidad Nacional de Tucumán, the Pontificia Universidad Católica de Chile, the Central Bank of Chile, the 2010 SED conference, the 2010 Berlin Conference on Sovereign Debt and Default, the Wilfrid Laurier University, the ECB, the World Bank, the 2011 NBER International Finance and Macroeconomics Workshop, Indiana University, the University of Wisconsin Madison, the 2012 Canadian Macro Study Group, the 2013 Barcelona GSE Summer Forum, and the XVI Di Tella Workshop in International Economics and Finance. Any remaining mistakes are our own. The views expressed herein are those of the authors and should not be attributed to the IMF, its Executive Board, or its management.

E-mails: juanc.hatchondo@gmail.com; leo14627@gmail.com; cesarspa@gmail.com. 


\begin{abstract}
We measure the effects of debt dilution on sovereign default risk and study debt covenants that could mitigate these effects. We calibrate a baseline model with endogenous debt duration and default risk (in which debt can be diluted) using data from Spain. We find that debt dilution accounts for 78 percent of the default risk in the baseline economy and that eliminating dilution increases the optimal duration of sovereign debt by almost two years. Eliminating dilution also increases consumption volatility, but still produces welfare gains. The debt covenants we study could help enforcing fiscal rules.
\end{abstract}




\section{Introduction}

The sovereign debt crisis that started to unfold in Greece in 2010 and spread to other European nations led to costly fiscal consolidations and disruptions in financial markets. The social costs of these events revived discussions about policies to mitigate the likelihood and the costs of debt crises. We contribute to these discussions by studying the effects of debt dilution on sovereign default risk.

Debt dilution refers to the reduction in the value of existing debt triggered by the issuance of new debt. Issuing new debt reduces the value of existing debt because it increases the probability of default. Three factors generate the sovereign debt dilution problem: (i) governments issue long-term debt, (ii) the current government cannot control debt issuances by future governments, and (iii) bonds are priced by rational investors. Rational investors anticipate that additional borrowing by future governments will increase the risk of default on long-term bonds issued by the current government and, thus, offer a lower price for these bonds. The current government could benefit from constraining future borrowing because this could increase the price of the bonds it issues. However, governments are typically unable to constrain borrowing by future governments, which creates the debt dilution problem.

Governments can also shorten the maturity of their debt to mitigate the debt dilution problem. Since investors are only concerned about borrowing that takes place prior to the maturity of the bonds they buy, a shorter maturity reduces the scope for diluting the value of these bonds. But shortening the maturity of debt is costly because it increases the economy's exposure to rollover risk, i.e., the risk of an increase in the cost of borrowing.

How important is debt dilution for sovereign default risk and the governments' choice of 
sovereign debt maturity? How can the effects of debt dilution be mitigated through changes in sovereign debt contracts? This paper contributes to answering these questions.

Several studies describe inefficiencies created by the debt dilution problem. Bizer and DeMarzo (1992) show how dilution may lead to equilibria with higher debt levels and higher interest rates implied by higher default probabilities. Kletzer (1984) argues that dilution may lead borrowers to rely excessively on short-term debt. Bolton and Jeanne (2009) show that dilution may promote the issuance of debt that is hard to restructure after a default, which in turn could increase the likelihood and/or severity of debt crises. However, in contrast with this paper, these studies do not quantify the effects of debt dilution.

Participants in various credit markets have made efforts to mitigate the dilution problem. For example, corporate debt contracts often include covenants intended to limit debt dilution (Asquith et al., 2005, Smith and Warner, 1979, Rodgers, 1965, and Carey et al., 1993). Corporate debt and mortgage loans to households typically feature a seniority structure that establishes the order of repayment to creditors after a default event-Bizer and DeMarzo (1992) show how the introduction of seniority may mitigate the dilution problem. In contrast, sovereign bonds typically do not present differences in seniority. These bonds include a pari passu clause and a negative pledge clause establishing that a bondholder's right to be repaid is not subordinated to the rights of other unsecured (pari passu) or secured (negative pledge) creditors. These clauses thus prevent debt from being made junior to other debt, but do not make debt senior to other debt. Overall, it seems clear that existing sovereign debt contracts do not address the risk of debt dilution.

We measure the effects of debt dilution using a default framework à la Eaton and Gersovitz (1981). Formally, we analyze a small open economy that receives a stochastic endowment 
stream of a single tradable good. At the beginning of each period, when the government is not in default, it decides whether to default on its debt. While in default, the government suffers an endowment loss and cannot borrow. Each period, a government in default may be offered the opportunity of exiting the default. In order to exit the default, the government must restructure the debt in default with a nominal haircut. As in Arellano and Ramanarayanan (2012), we assume the government can issue both short-term and long-term non-contingent bonds, and thus is able to choose the duration of its debt portfolio. Bonds are priced by competitive foreign investors with recursive preferences as in Epstein and Zin (1989) and Weil (1989). The (exogenous) consumption process of foreign investors is subject to shocks, which introduces time variation in the term structure of default-free bonds.

We impose discipline on our quantitative exercise by calibrating the baseline model to match data from Spain, an economy facing default risk. We calibrate the model to match the level and average duration of government debt, and the average interest rate spread for long-term sovereign bonds. We show that the model also generates plausible implications for consumption volatility, the countercyclicality of the trade balance, the average interest rate spread for short-term sovereign bonds, and the fraction of total debt obligations that mature within one year. The overall match between the model predictions and the data makes the model a good laboratory for the quantitative exercises we conduct in this paper.

We propose a new approach for the study of the effects of debt dilution. First, we modify the baseline model by assuming that long-term sovereign bonds include the following covenant: each time the government borrows, it has to compensate the holders of long-term debt issued in previous periods by paying the difference between the observed long-term bond price and the counterfactual price that would have been observed in the absence of current- 
period borrowing. This covenant makes long-term bond prices independent from future borrowing and thus eliminates dilution. We measure the effects of dilution by comparing simulations of the baseline model (with dilution) with those of the modified model (without dilution).

We find that, if the sovereign eliminates debt dilution, the number of defaults per 100 years decreases from 2.8 to 0.6 . That is, dilution accounts for 78 percent of the default risk in the simulations of the baseline model. This exercise shows the quantitative importance of dilution and supports the inclusion of dilution in discussions of sovereign debt management and of reforms in the international financial architecture (e.g., Borensztein et al., 2004).

The bond covenant that eliminates dilution also allows the government to lower its exposure to rollover risk. In our benchmark economy, the government shortens the duration of its debt portfolio to mitigate the dilution problem at the expense of increasing rollover risk (Arellano and Ramanarayanan, 2012; Hatchondo and Martinez, 2013). With the debt covenant that eliminates dilution, it is optimal for the government to lower its exposure to rollover risk by increasing the duration of its debt portfolio. The average debt duration in the simulations is almost two years higher in the model without dilution than in the benchmark.

The second contribution of this paper is to discuss how debt covenants that are easier to implement in practice could mitigate dilution. The covenant that eliminates dilution may be difficult to implement because computing the payments mandated by this covenant requires knowledge of an unobservable variable: the price at which long-term bonds would trade without current-period borrowing. Nonetheless, we show that most gains from eliminating dilution can be obtained with simpler covenants that do not depend on this counterfactual bond price. We study two covenants that penalize the government for either (i) choosing 
debt levels above a threshold or (ii) borrowing at bond prices below a threshold. We find that the first covenant is more effective in reducing consumption volatility and the second one is more effective in reducing the default frequency. The implementation of these covenants could also help enforce the growing number of fiscal rules that countries impose to deal with over-borrowing (Schaechter et al., 2012).

Our findings are not based on the assumption that the government cannot default on covenant payments in the same way that it can default on other debt payments. We only assume that defaulting on covenant payments triggers acceleration and cross-default clauses and, therefore, a default on all government debt. Acceleration clauses allow creditors to accelerate all future payments owed to them if pre-defined events of default take place. Cross-default clauses state that a default on any government obligation constitutes a default on the contract containing that clause. These clauses imply that in practice, when the government chooses to default on some payment obligation, it chooses to default on all its debt.

The debt covenants that we study in this paper resemble covenants commonly used in debt markets. For instance, Chamon and Mauro (2006) show that in 2001, 26 percent of government debt in emerging economies was indexed to a domestic interest rate (an additional 7 percent was indexed to inflation). One debt covenant that we propose imposes debt payments that are a decreasing function of the sovereign bond prices. Thus, this covenant indexes debt payments to an interest rate that reflects default risk. In corporate debt contracts, covenants often transfer resources from debtors to creditors when credit quality deteriorates, which can be reflected in credit rating, leverage ratios, or other measures of financial performance. Asquith et al. (2005) document the use and effects of such "interest- 
increasing performance pricing". They find that interest rates are lower for debt contracts that feature these covenants, which is consistent with our results.

\subsection{Related literature}

The most common modeling approach for the study of debt dilution is to focus on the effect of seniority clauses (Bi, 2006; Chatterjee and Eyigungor, 2013). However, when new borrowing increases the default probability, seniority does not fully eliminate debt dilution (Bizer and DeMarzo, 1992). Therefore, in general, one cannot measure accurately the effects of dilution by comparing equilibria with and without seniority. Furthermore, seniority clauses may not be a practical instrument for curbing debt dilution in sovereign debt markets given that the weak enforcement of sovereign debt claims could be an obstacle to implementing a meaningful seniority structure: governments typically exit defaults by offering a debt exchange that must be accepted by a sufficiently high fraction of bondholders. This limits the degree of discrimination that can be implemented with seniority clauses (holders of junior debt may not want to participate in the exchange). In contrast, the enforcement we assume on the payments imposed by debt covenants is not stronger than the enforcement assumed on any other debt payment obligation.

A second approach to the study of debt dilution is to compare equilibria obtained with long-term and one-period bonds. This is done in environments with an exogenous debt duration. ${ }^{1}$ However, this approach is ill-suited for isolating the effects of debt dilution. As

\footnotetext{
${ }^{1}$ Intertemporal debt dilution only appears with long-term bonds. With one-period bonds, when the government decides its current issuance level, the outstanding debt level is zero (either because the government honored its debt obligations at the beginning of the period or because it defaulted on them). Thus, the government cannot dilute the value of debt issued in previous periods. Chatterjee and Eyigungor (2012) and Hatchondo and Martinez (2009) show that in a sovereign default framework, equilibrium default risk is significantly higher with long-term bonds than with one-period bonds.
} 
discussed by Chatterjee and Eyigungor (2012), a model with only long-term debt in which creditors are fully compensated for any increase or decrease in the value of their debt claims is isomorphic to a model with only one-period bonds. Importantly, these compensation payments depend on the entire change in bond prices, not only on the fraction of the price change that is caused by borrowing decisions. This means that a model with one-period debt does more than just eliminate debt dilution. For instance, an environment in which the government issues only one-period debt may feature a lower default frequency not only because the government issues debt that cannot be diluted away but also because the government may choose to carry lower debt levels in order to mitigate the higher rollover risk implied by issuing only one-period bonds. Note that in our benchmark model, the government could potentially choose a debt portfolio with only one-period bonds but does not find it optimal to do so.

The covenants discussed in this paper also resemble taxes used in previous studies for eliminating over-borrowing by private debtors (see Bianchi, 2011, and the references therein). In these studies, individual borrowers do not internalize the way their actions affect the cost of borrowing. Thus, taxing borrowing is welfare enhancing. In this paper, borrowing by future governments increases the current government's cost of borrowing. The debt covenants that we study "tax" borrowing by future governments and are welfare enhancing.

The rest of the article proceeds as follows. Section 2 introduces the baseline model with dilution. Section 3 presents the model without dilution. Section 4 discusses the calibration. Section 5 presents the results. Section 6 concludes. 


\section{Baseline model with dilution}

The baseline model captures the interaction between foreign lenders and a small sovereign borrower with limited commitment. It extends the canonical Eaton and Gersovitz (1981) model in three dimensions: (i) the borrower can issue both a one-period bond and a longterm bond, making the average duration of sovereign debt endogenous, (ii) bondholders are risk averse and are subject to shocks, and (iii) the recovery rate of debt in default is positive.

\subsection{The baseline environment}

Local endowment and preferences. There is a single tradable good. The domestic economy receives a stochastic endowment stream $y_{t}$ of this good, where $y_{t}$ follows a Markov process.

The government's objective is to maximize the present expected discounted value of future utility flows of the representative agent in the economy, namely

$$
E\left[\sum_{t=0}^{\infty} \beta^{t} u\left(c_{t}\right)\right],
$$

where $E$ denotes the expectation operator, $\beta$ denotes the subjective discount factor, and the utility function is assumed to show a constant coefficient of relative risk aversion denoted by $\gamma$. That is,

$$
u(c)=\frac{c^{1-\gamma}}{1-\gamma}
$$

Asset space. As in Arellano and Ramanarayanan (2012), we assume that the government can issue a one-period bond and a long-term bond. As in Hatchondo and Martinez (2009) and Arellano and Ramanarayanan (2012), we assume that a long-term bond issued in period 
$t$ entails a promise to pay $(1-\delta)^{s-1}$ units of the good in period $t+s$, for all $s \geq 1$. The advantage of this payment structure is that it enables us to condense all future payment obligations derived from past long-term debt issuances into a one-dimensional state variable: the quantity of long-term coupon obligations that mature in the current period.

Each period, the government makes two decisions. First, it decides whether to default. Second, it rebalances its debt portfolio. This implies that the duration of the debt portfolio is endogenous, which is an important feature of the model given that the government's ability to dilute debt depends on the debt duration.

Lenders. We assume that the kernel that prices bonds issued by the domestic government is similar to the one that has been used in recent studies that account for the price behavior of U.S. government bonds. The growth rate of bondholders' consumption (denoted by $g^{*}$ ) follows an $\mathrm{AR}(1)$ process, namely

$$
\log \left(g_{t}^{*}\right)=\left(1-\rho^{*}\right) \mu_{g^{*}}+\rho^{*} \log \left(g_{t-1}^{*}\right)+\varepsilon_{t}^{*}
$$

where $\mu_{g^{*}}$ denotes the mean consumption growth, $\left|\rho^{*}\right|<1$, and $\varepsilon_{t}^{*} \sim N\left(0, \sigma_{\epsilon^{*}}^{2}\right)$.

Bondholders' preferences can be described by the recursive utility model proposed by Epstein and Zin (1989) and Weil (1989), which allows for a constant coefficient of relative risk aversion that can differ from the reciprocal of the inter-temporal elasticity of substitution. Bondholders' preferences are thus described by

$$
\log \left(V^{*}\left(c_{t}^{*}, g_{t}^{*}\right)\right)=\left(1-\beta^{*}\right) \log \left(c_{t}^{*}\right)+\frac{\beta^{*}}{1-\gamma^{*}} \log \left(E\left[V^{*}\left(c_{t+1}^{*}, g_{t+1}^{*}\right)^{1-\gamma^{*}} \mid g_{t}^{*}\right]\right)
$$


where $c_{t}^{*}$ denotes bondholders' consumption in period $t, \beta^{*}$ denotes their discount factor, and $\gamma^{*}$ denotes their coefficient of relative risk aversion. This preference specification assumes a unitary elasticity of inter-temporal substitution. Since preferences are homothetic, the function $V^{*}$ depends linearly on $c^{*}$, and thus

$$
\log \left(V^{*}\left(c_{t}^{*}, g_{t}^{*}\right)\right)=\log \left(c_{t}^{*}\right)+\log \left(\tilde{V}^{*}\left(g_{t}^{*}\right)\right)
$$

with

$$
\log \left(\tilde{V}^{*}\left(g_{t}^{*}\right)\right)=\frac{\rho^{*} \beta^{*}}{1-\rho^{*} \beta^{*}} \log \left(g_{t}^{*}\right)+\frac{\left(1-\rho^{*}\right) \beta^{*}}{\left(1-\beta^{*}\right)\left(1-\rho^{*} \beta^{*}\right)} \log \left(\mu_{g^{*}}\right)+\frac{1}{2} \frac{\left(1-\gamma^{*}\right) \beta^{*}}{\left(1-\beta^{*}\right)\left(1-\rho^{*} \beta^{*}\right)^{2}} \sigma_{\epsilon^{*}}^{2} .
$$

The bondholders' stochastic discount factor can be expressed as

$$
M\left(g_{t}^{*}, g_{t+1}^{*}\right)=\beta^{*} \frac{g_{t+1}^{*}-\gamma^{*} \tilde{V}^{*}\left(g_{t+1}^{*}\right)^{1-\gamma^{*}}}{E\left[\left[g_{t+1}^{*} \tilde{V}^{*}\left(g_{t+1}^{*}\right)\right]^{1-\gamma^{*}} \mid g_{t}^{*}\right]},
$$

where $M\left(g_{t}^{*}, g_{t+1}^{*}\right)$ denotes the value that bondholders assign to a payment of one unit of the good when their consumption growth rate in the next period is $g_{t+1}^{*}$ and their current consumption growth rate is $g_{t}^{*}$.

This pricing kernel assumes that (i) the debt issued by the domestic government represents a small fraction of bondholders' wealth, and thus, default decisions or variations in the market value of that debt do not affect bondholders' consumption, and (ii) domestic and foreign shocks are uncorrelated.

Defaults. We assume that when the government defaults, it does so on all current and future debt obligations. This is consistent with the behavior of defaulting governments in 
reality. As mentioned in the introduction, sovereign debt contracts often contain acceleration and cross-default clauses. These clauses imply that after a default event, future debt obligations become current.

In order to sustain positive debt levels, we assume that sovereign defaults are costly. Once the government declares a default, it remains in default for a stochastic number of periods. While the government is in default, it cannot issue debt and domestic aggregate income is reduced by $\phi(y)$. As in Arellano (2008) and Chatterjee and Eyigungor (2012), we assume that it is proportionally more costly to default in good times $(\phi(y) / y$ is increasing in $y$ ). They show that this property is important in accounting for the dynamics of the sovereign debt interest rate spread. Mendoza and Yue (2012) show that this property of the cost of defaulting arises endogenously in a setup in which defaults affect the ability of local firms to acquire a foreign intermediate input good. Borensztein and Panizza (2009) survey previous work about the costs of defaults and also present their own estimations. They find statistical evidence suggesting that while output may fall following a sovereign default, the effect is short-lived, not lasting for more than one year. ${ }^{2}$ They find evidence of other costs of defaulting including reputational costs (lower credit rating and higher borrowing cost after a default) and disruptions in international trade, and find that these other costs seem to be more long lived.

We capture in a simple fashion the positive recovery rate of debt in default observed in the data (see Cruces and Trebesch, 2013, and Benjamin and Wright, 2008). Starting

\footnotetext{
${ }^{2}$ Borensztein and Panizza (2009) find that the output growth rate tends to be 2.6 percent lower one year after the default, but no statistically significant effect is found for longer lags. Furthermore, Borensztein and Panizza (2009) warn that their estimations do not fully control for endogeneity biases and, thus, it is not clear what fraction of the measured effect on output is caused by defaults per se. In addition, they show that output falls prior to the default, which could be attributed to adverse effects caused by the anticipation of the default (see also Levy Yeyati and Panizza, 2011).
} 
from the first period after the government defaults, the government is presented with the opportunity to end the default with time-invariant probability $\xi$. In order to end the default, the government needs to replace the bonds in default with bonds that promise to pay $\alpha<1$ times the payments promised by the replaced bonds. Thus, the maturity structure of the new debt is the same as that of the debt in default. The government may choose not to restructure the debt and continue in default, in which case its debt level will still be $\alpha$ times the debt level before the restructuring opportunity (thus, the government can obtain a lower recovery rate at the expense of a longer default period). During default, the government's payment obligations grow at the average short-term interest rate, $r$, which satisfies

$$
\frac{1}{1+r}=E_{g_{t}^{*}}\left[E_{g_{t+1}^{*}}\left[M\left(g_{t}^{*}, g_{t+1}^{*}\right) \mid g_{t}^{*}\right]\right] .
$$

In a model with long-term debt, a positive recovery rate may give the government incentives to issue large amounts of debt before defaulting, which would allow for a large increase in consumption (Hatchondo et al., 2014). In order to avoid this problem, we assume that the government cannot sell defaultable bonds with a price lower than $\underline{q}$ (the secondary market price of government debt can still be lower than $\underline{q}$ ). We choose a value of $\underline{q}$ that eliminates consumption booms before defaults. The chosen value is also rarely binding, and allows for debt issuances at the sovereign spreads observed in the data (see Section 4).

Equilibrium concept. The government cannot commit to future default and borrowing decisions. Thus, one may interpret this environment as a game in which the government making the default and borrowing decisions in period $t$ is a player who takes as given the default and borrowing strategies of other players (governments) who will decide after $t$. We 
focus on Markov Perfect Equilibria. That is, we assume that in each period, the government's equilibrium default and borrowing strategies depend only on payoff-relevant state variables.

\subsection{Recursive formulation of the baseline environment}

We present next the recursive formulation of the model described above. We denote with $x^{\prime}$ the value of a variable $x$ in the next period. Let $b_{S}$ denote the quantity of one-period bonds that mature in the current period, and $b_{L}$ denote the quantity of long-term coupon obligations that mature in the current period. Let $q_{S}$ denote the bond price function for short-term debt, and $q_{L}$ denote the bond price function for long-term debt.

Continuation values given future borrowing and defaulting rules. Let $\hat{d}, \hat{b}_{S}$, and $\hat{b}_{L}$ denote rules followed by future governments for defaulting ( 1 for default, 0 otherwise), short-term borrowing (choice of $b_{S}^{\prime}$ ) and long-term borrowing (choice of $b_{L}^{\prime}$ ). Let $V, V^{R}$, and $V^{D}$ denote respectively the continuation values before the default decision, after the government chooses to repay, and after the government defaults, given the decision rules $\left(\hat{d}, \hat{b}_{S}, \hat{b}_{L}\right)$. Thus, the function $V$ is given by

$$
V\left(b_{S}, b_{L}, y, g^{*}\right)=\hat{d}\left(b_{S}, b_{L}, y, g^{*}\right) V^{D}\left(b_{S}, b_{L}, y, g^{*}\right)+\left[1-\hat{d}\left(b_{S}, b_{L}, y, g^{*}\right)\right] V^{R}\left(b_{S}, b_{L}, y, g^{*}\right)
$$

The function $V^{R}$ is given by 


$$
V^{R}\left(b_{S}, b_{L}, y, g^{*}\right)=u(c)+\beta E_{y^{\prime}, g^{* \prime}}\left[V\left(b_{S}{ }^{\prime}, b_{L}{ }^{\prime}, y^{\prime}, g^{* \prime}\right) \mid y, g^{*}\right],
$$

subject to

$$
c=y-b_{L}-b_{S}+q_{L}\left(b_{S}{ }^{\prime}, b_{L}{ }^{\prime}, y, g^{*}\right)\left[b_{L}{ }^{\prime}-(1-\delta) b_{L}\right]+q_{S}\left(b_{S}{ }^{\prime}, b_{L}{ }^{\prime}, y, g^{*}\right) b_{S}{ }^{\prime}
$$

where $b_{S}{ }^{\prime}=\hat{b}_{S}\left(b_{S}, b_{L}, y, g^{*}\right), b_{L}{ }^{\prime}=\hat{b}_{L}\left(b_{S}, b_{L}, y, g^{*}\right)$. The function $V^{D}$ is given by

$$
\begin{aligned}
& V^{D}\left(b_{S}, b_{L}, y, g^{*}\right)=u(c)+\beta E_{y^{\prime}, g^{* \prime}}\left[(1-\xi) V^{D}\left(b_{S^{\prime}}{ }^{\prime}, b_{L}{ }^{\prime}, y^{\prime}, g^{* \prime}\right)+\xi V\left(\alpha b_{S}{ }^{\prime}, \alpha b_{L}{ }^{\prime}, y^{\prime}, g^{* \prime}\right) \mid y, g^{*} \backslash 4\right) \\
& \text { subject to } \\
& c=y-\phi(y), \\
& b_{S^{\prime}}{ }^{\prime}=b_{S}(1+r), \text { and } \\
& b_{L}{ }^{\prime}=b_{L}(1+r) .
\end{aligned}
$$

Bond prices. The price of one-period bonds is given by

$$
q_{S}\left(b_{S}{ }^{\prime}, b_{L}{ }^{\prime}, y, g^{*}\right)=E_{y^{\prime}, g^{* \prime}}\left[M\left(g^{*}, g^{* \prime}\right)\left(1-d^{\prime}+d^{\prime} q_{S}^{D^{\prime}}\right) \mid y, g^{*}\right],
$$

where $d^{\prime}=\hat{d}\left(b_{S}{ }^{\prime}, b_{L}{ }^{\prime}, y^{\prime}, g^{* \prime}\right)$ denotes the default decision in the next period and $q_{S}^{D^{\prime}}=$ $q_{S}^{D}\left(b_{S}{ }^{\prime}, b_{L}{ }^{\prime}, y^{\prime}, g^{* \prime}\right)$ denotes the value of one-period bonds in default in the next period, which is given by 


$$
q_{S}^{D}\left(b_{S}{ }^{\prime}, b_{L}{ }^{\prime}, y, g^{*}\right)=E_{y^{\prime}, g^{* \prime}}\left[(1+r) M\left(g^{*}, g^{* \prime}\right)\left[(1-\xi) q_{S}^{D^{\prime}}+\xi \alpha\left(1-d^{\prime}+d^{\prime} q_{S}^{D D^{\prime}}\right)\right] \mid y, g^{*}\right]
$$

where $q_{S}^{D^{\prime}}=q_{S}^{D}\left((1+r) b_{S}{ }^{\prime},(1+r) b_{L}{ }^{\prime}, y^{\prime}, g^{* \prime}\right)$ denotes the value of one-period bonds in default in the next period, $d^{\prime}=\hat{d}\left((1+r) \alpha b_{S}{ }^{\prime},(1+r) \alpha b_{L}{ }^{\prime}, y^{\prime}, g^{* \prime}\right)$ denotes the default decision in the next period after debt is reduced, and $q_{S}^{D D^{\prime}}=q_{S}^{D}\left((1+r) \alpha b_{S}{ }^{\prime},(1+r) \alpha b_{L}{ }^{\prime}, y^{\prime}, g^{* \prime}\right)$ denotes the value of a one-period bond after debt is reduced by $\alpha$ but the government chooses to remain in default.

The price of long-term bonds is given by

$$
q_{L}\left(b_{S}{ }^{\prime}, b_{L}{ }^{\prime}, y, g^{*}\right)=E_{y^{\prime}, g^{* \prime}}\left[M\left(g^{*}, g^{* \prime}\right)\left[\left(1-d^{\prime}\right)\left[1+(1-\delta) q_{L}{ }^{\prime}\right]+d^{\prime} q_{L}^{D \prime}\right] \mid y, g^{*}\right]
$$

where $q_{L}^{\prime}=q_{L}\left(b_{S}{ }^{\prime \prime}, b_{L}{ }^{\prime \prime}, y^{\prime}, g^{* \prime}\right)$ denotes the value of long-term bonds in the next period when the government repays its debt obligations, $b_{S}{ }^{\prime \prime}=\hat{b}_{S}\left(b_{S}{ }^{\prime}, b_{L}{ }^{\prime}, y^{\prime}, g^{* \prime}\right)$ denotes the short-term borrowing decision in the next period after repayment, $b_{L}{ }^{\prime \prime}=\hat{b}_{L}\left(b_{S}{ }^{\prime}, b_{L}{ }^{\prime}, y^{\prime}, g^{* \prime}\right)$ denotes the long-term borrowing decision in the next period after repayment, and $q_{L}^{D^{\prime}}=$ $q_{L}^{D}\left(b_{S}{ }^{\prime}, b_{L}{ }^{\prime}, y^{\prime}, g^{* \prime}\right)$ denotes the value of a long-term bond in default in the next period, which is given by

$$
q_{L}^{D}\left(b_{S}{ }^{\prime}, b_{L}{ }^{\prime}, y, g^{*}\right)=E_{y^{\prime}, g^{* \prime}}\left[(1+r) M\left(g^{*}, g^{* \prime}\right)\left[(1-\xi) q_{L}^{D \prime}+\xi \alpha\left(\left(1-d^{\prime}\right)\left(1+(1-\delta) q_{L}^{\prime}\right)+d^{\prime} q_{L}^{D \prime}\right)\right] \mid y, g^{*}\right]
$$

where $q_{L}^{D \prime}=q_{L}^{D}\left((1+r) b_{S}{ }^{\prime},(1+r) b_{L}{ }^{\prime}, y^{\prime}, g^{* \prime}\right)$ denotes the value of a long-term bond in default in the next period, $q_{L}^{\prime}=q_{L}\left(b_{S}^{D^{\prime \prime}}, b_{L}^{D^{\prime \prime}}, y^{\prime}, g^{* \prime}\right)$ denotes the value of a long-term bond in 
the next period if the government exits the default, $b_{S}^{D^{\prime \prime}}=\hat{b}_{S}\left((1+r) \alpha b_{S}{ }^{\prime},(1+r) \alpha b_{L}{ }^{\prime}, y^{\prime}, g^{* \prime}\right)$ denotes the short-term borrowing decision in the next period after exiting the default, $b_{L}^{D^{\prime \prime}}=\hat{b}_{L}\left((1+r) \alpha b_{S}{ }^{\prime},(1+r) \alpha b_{L}{ }^{\prime}, y^{\prime}, g^{* \prime}\right)$ denotes the long-term borrowing decision in the next period after exiting the default, and $q_{L}^{D{ }^{\prime \prime}}=q_{L}^{D}\left((1+r) \alpha b_{S}{ }^{\prime}, \alpha(1+r) b_{L}{ }^{\prime}, y^{\prime}, g^{* \prime}\right)$ denotes the value of a long-term bond when the government chooses to stay in default after the debt has been reduced.

\section{Current optimal decisions given bond prices and future borrowing and defaulting}

rules. In the current period, the government optimally chooses whether to default and how much debt to issue (if it does not default). The optimal default decision solves

$$
\max _{d \in\{0,1\}}\left\{d V^{D}\left(b_{S}, b_{L}, y, g^{*}\right)+(1-d) V^{R}\left(b_{S}, b_{L}, y, g^{*}\right)\right\}
$$

where $d$ equals $1(0)$ if the government chooses to (not to) default. The optimal borrowing decisions solve

$$
\begin{aligned}
& \max _{b_{S^{\prime}}, b_{L}{ }^{\prime} \geq 0}\left\{u(c)+\beta E_{y^{\prime}, g^{* \prime}}\left[V\left(b_{S}{ }^{\prime}, b_{L}{ }^{\prime}, y^{\prime}, g^{* \prime}\right) \mid y, g^{*}\right]\right\}, \\
& \text { subject to }
\end{aligned}
$$$$
c=y-b_{L}-b_{S}+q_{L}\left(b_{S}{ }^{\prime}, b_{L}{ }^{\prime}, y, g^{*}\right)\left[b_{L}{ }^{\prime}-(1-\delta) b_{L}\right]+q_{S}\left(b_{S}{ }^{\prime}, b_{L}{ }^{\prime}, y, g^{*}\right) b_{S}{ }^{\prime} \text {, and }
$$$$
b_{L}{ }^{\prime} \text { may be higher than }(1-\delta) b_{L} \text { only if } q_{L}\left(b_{S}{ }^{\prime}, b_{L}{ }^{\prime}, y, g^{*}\right) \geq \underline{q} \text {. }
$$

Equilibrium definition. A Markov Perfect Equilibrium is characterized by policy rules $\hat{d}, \hat{b}_{S}, \hat{b}_{L}$ such that 
(a) Given $\hat{d}, \hat{b}_{S}$, and $\hat{b}_{L}$, the value functions $V, V^{R}$, and $V^{D}$ satisfy functional equations $(2)-(4)$

(b) Given $\hat{d}, \hat{b}_{S}, \hat{b}_{L}$, the bond price functions $q_{S}$ and $q_{L}$ satisfy functional equations (5)-(8).

(c) The function $\hat{d}\left(b_{S}, b_{L}, y, g^{*}\right)$ solves (9) for all $b_{S}, b_{L}, y, g^{*}$.

(d) The functions $\hat{b}_{S}\left(b_{S}, b_{L}, y, g^{*}\right)$ and $\hat{b}_{L}\left(b_{S}, b_{L}, y, g^{*}\right)$ jointly solve (10) for all $b_{S}, b_{L}, y$, $g^{*}$.

\section{A model without debt dilution}

In this section, we propose a modification to the model presented in Section 2 that will allow us to study an economy without debt dilution and, in turn, to measure the effects of debt dilution. We eliminate debt dilution - caused by borrowing decisions - by introducing a debt covenant. The covenant specifies that if the sovereign borrows, it has to pay each holder of previously-issued long-term bonds the difference between the counterfactual bond price that would have been observed absent new borrowing in the current period $\left(q_{L}\left(0, b_{L}(1-\delta), y, g^{*}\right)\right)$ and the observed bond price $\left(q_{L}\left(b_{S}{ }^{\prime}, b_{L}{ }^{\prime}, y, g^{*}\right)\right)$. This covenant eliminates debt dilution by making the value of long-term bonds independent of future borrowing decisions.

Assuming that the bond price is decreasing in both short-term and long-term debt (we find that this is the case in our numerical solution), the payment specified in the covenant is given by

$$
\mathcal{C}\left(b_{L}, y, g^{*}, b_{S}{ }^{\prime}, b_{L}{ }^{\prime}\right)=\operatorname{Max}\left\{q_{L}\left(0, b_{L}(1-\delta), y, g^{*}\right)-q_{L}\left(b_{S}{ }^{\prime}, b_{L}{ }^{\prime}, y, g^{*}\right), 0\right\}
$$


The government's budget constraint when it repays its debt reads as

$$
c=y-b_{L}-b_{S}+q_{L}\left(b_{S}{ }^{\prime}, b_{L}{ }^{\prime}, y, g^{*}\right)\left[b_{L}{ }^{\prime}-(1-\delta) b_{L}\right]+q_{S}\left(b_{S}{ }^{\prime}, b_{L}{ }^{\prime}, y, g^{*}\right) b_{S}{ }^{\prime}-(1-\delta) b_{L} \mathcal{C}\left(b_{L}, y, g^{*}, b_{S}{ }^{\prime}, b_{L}{ }^{\prime}\right)
$$

The price of a long-term bond is given by

$$
q_{L}\left(b_{S}{ }^{\prime}, b_{L}{ }^{\prime}, y, g^{*}\right)=E_{y^{\prime}, g^{* \prime}}\left[M\left(g^{*}, g^{* \prime}\right)\left[\left(1-d^{\prime}\right)\left[1+(1-\delta)\left(q_{L}^{\prime}+\mathcal{C}^{\prime}\right)\right]+d^{\prime} q_{L}^{D \prime}\right] \mid y, g^{*}\right]
$$

where $\mathcal{C}^{\prime}=\mathcal{C}\left(b_{L}{ }^{\prime}, y^{\prime}, g^{*^{\prime}}, \hat{b}_{S}\left(b_{S}{ }^{\prime}, b_{L}{ }^{\prime}, y^{\prime}, g^{* \prime}\right), \hat{b}_{L}\left(b_{S}{ }^{\prime}, b_{L}{ }^{\prime}, y^{\prime}, g^{* \prime}\right)\right)$ denotes the payment mandated by the covenant in the next period, and $q_{L}^{D \prime}$ denotes the price of a long-term bond in default in the next period, which satisfies:

$$
q_{L}^{D}\left(b_{S}{ }^{\prime}, b_{L}{ }^{\prime}, y, g^{*}\right)=E_{y^{\prime}, g^{* \prime}}\left[(1+r) M\left(g^{*}, g^{* \prime}\right)\left[(1-\xi) q_{L}^{D \prime}+\xi \alpha\left[\left(1-d^{\prime}\right)\left(1+(1-\delta)\left(q_{L}{ }^{\prime}+\mathcal{C}^{D \prime}\right)\right)+d^{\prime} q_{L}^{D D^{\prime}}\right]\right] \mid y, g^{*}\right]
$$

where

$$
\mathcal{C}^{D \prime}=\mathcal{C}\left((1+r) \alpha b_{L}{ }^{\prime}, y^{\prime}, g^{*^{\prime}}, \hat{b}_{S}\left((1+r) \alpha b_{S}{ }^{\prime},(1+r) \alpha b_{L}{ }^{\prime}, y^{\prime}, g^{* \prime}\right), \hat{b}_{L}\left((1+r) \alpha b_{S}{ }^{\prime},(1+r) \alpha b_{L}{ }^{\prime}, y^{\prime}, g^{* \prime}\right)\right)
$$

denotes the payment mandated by the covenant in the next period when the government exits default.

We assume that the same enforcement mechanism that prevents selective defaults on coupon payments alone applies to the payments mandated by the covenant. The equilibrium definition with covenant payments differs in two ways with respect to the one for the baseline model: (i) the budget constraint (12) replaces the budget constraints in (3) and (10), and (ii) functional equations (13)-(14) replace functional equations (7)-(8).

Note that the issuance proceeds that the government obtains with the debt covenant in equation (11) are exactly the same as those it would obtain from an exclusive lender. Suppose 
the government is forced to sell its debt to an exclusive lender who holds all sovereign debt. Suppose that in each period the government can make a take-it-or-leave-it offer to this lender specifying the number of bonds it wants to issue $\left(\left[b_{L}{ }^{\prime}-(1-\delta) b_{L}\right]\right.$ and $\left.b_{S}{ }^{\prime}\right)$ and the amount it wants in exchange for these bonds (the take-it-or-leave-it assumption guarantees that the lender does not profit from its exclusivity status, allowing us to distinguish the effects of exclusivity from the effects of competitive debt markets). If the exclusive lender does not accept this offer, the government cannot issue debt in the current period and the value of its debt holdings is $q_{L}\left(0, b_{L}(1-\delta), y, g^{*}\right) b_{L}(1-\delta)$. If the exclusive lender accepts the offer, the value of its debt holdings is $q_{L}\left(b_{S}{ }^{\prime}, b_{L}{ }^{\prime}, y, g^{*}\right) b_{L}{ }^{\prime}+q_{S}\left(b_{S}{ }^{\prime}, b_{L}{ }^{\prime}, y, g^{*}\right) b_{S}{ }^{\prime}$. Therefore, in exchange for $\left[b_{L}{ }^{\prime}-(1-\delta) b_{L}\right]$ and $b_{S}{ }^{\prime}$, the exclusive lender gives to the government $q_{L}\left(b_{S}{ }^{\prime}, b_{L}{ }^{\prime}, y, g^{*}\right) b_{L}{ }^{\prime}+$ $q_{S}\left(b_{S}{ }^{\prime}, b_{L}{ }^{\prime}, y, g^{*}\right) b_{S}{ }^{\prime}-q_{L}\left(0, b_{L}(1-\delta), y, g^{*}\right) b_{L}(1-\delta)$, and consumption is given by

$c=y-b_{L}-b_{S}+q_{L}\left(b_{S}{ }^{\prime}, b_{L}{ }^{\prime}, y, g^{*}\right) b_{L}{ }^{\prime}+q_{S}\left(b_{S}{ }^{\prime}, b_{L}{ }^{\prime}, y, g^{*}\right) b_{S}{ }^{\prime}-q_{L}\left(0, b_{L}(1-\delta), y, g^{*}\right) b_{L}(1-\delta)$,

which is exactly the consumption implied by debt issuances with the covenant that eliminates dilution (equation 12).

\section{Calibration}

Table 1 presents the baseline parameterization. We use a peripheral European economy (Spain) to discipline the parameter values corresponding to the sovereign borrower. A period in the model refers to a quarter. The domestic endowment process follows an AR(1) process:

$$
\log \left(y_{t}\right)=(1-\rho) \mu_{y}+\rho \log \left(y_{t-1}\right)+\varepsilon_{t}
$$


with $\varepsilon_{t} \sim N\left(0, \sigma_{\epsilon}^{2}\right)$.

We estimate equation (15) using quarterly real GDP data from Spain ranging from the first quarter of 1960 to the first quarter of 2013. The data counterpart of $\log \left(y_{t}\right)$ is the deviation of the natural logarithm of GDP from its linear trend. García-Cicco et al. (2010) and Alvarez-Parra et al. (2013) estimate a standard business-cycle model for small open economies in which aggregate income is affected by two shocks to the state of technology: a standard stationary shock, and a non-stationary shock that affects the growth rate of productivity. They find that the role of the non-stationary technology shock significantly diminishes once the estimation procedure includes an ad-hoc state-dependent interest rate scheme at which the sovereign can borrow in foreign markets. For instance, using Mexican data, García-Cicco et al. (2010) find that the non-stationary (stationary) technology shock accounts for 7.4 (84.2) percent of the variance of aggregate income growth. The contribution of the non-stationary technology shock to the variance of other aggregate variables is even lower. Given that our model features a state-dependent interest scheme (which is endogenous), the findings in those papers suggest that allowing for a non-stationary income shock would likely involve a modest contribution to business cycle dynamics. Since allowing for a non-stationary income shock would require the use of an extra state variable, we specify the domestic income process as a stationary $\mathrm{AR}(1)$ process.

We assume that the representative agent in the sovereign economy has a coefficient of relative risk aversion $\gamma$ of 2 and a discount factor $\beta$ of 0.98 . Those values are within the range of accepted values in studies of business cycles in small open economies. For instance, those are the values used in García-Cicco et al. (2010) and in Alvarez-Parra et al. (2013).

With respect to the parameters governing the pricing kernel, we use NIPA data for the 
U.S. to estimate the process for bondholders' consumption growth. Bondholders' consumption consists of personal consumption expenditures in non-durable goods and in services. We estimate equation (1) using data ranging from the second quarter of 1952 to the fourth quarter of 2005 . We choose the parameter value for the bondholders' discount factor $\beta^{*}$ so that the mean quarterly real default-free interest rate equals 1 percent, which is the standard value in the sovereign default literature. We use the parameter value for the bondholders' coefficient of relative risk aversion $\gamma^{*}$ presented by Piazzesi and Schneider (2007). In a standard representative agent model, a high value of the bondholders' risk aversion parameter is needed to explain the (nominal) term premium in the U.S. given the relatively low volatility of aggregate consumption growth. Subsection 5.10 shows that the value of the bondholders' risk aversion parameter does not significantly affect the quantification of the role of debt dilution on sovereign default risk and on the choice of debt maturity.

We calibrate the probability with which a government has an opportunity to exit default $(\xi)$ so that the government remains in exclusion for an average of three years after a default (the government always takes this opportunity in the simulations). Using their partial access definition of re-entry, Dias and Richmond (2009) estimate a median duration of exclusion of three years. A three-year exclusion period is also in the range of estimates reported by Gelos et al. (2011).

The recovery rate of debt in default $(\alpha)$ is 0.63 . This is the average recovery rate reported by Cruces and Trebesch (2013) using a sample of 180 default episodes between 1970 and 2010 .

The minimum issuance price for long-term debt $(\underline{q})$ equals 70 percent of the mean defaultfree price of long-term debt. This implies that the government cannot issue debt with an 
annual yield to maturity higher than 9.7 percent. $^{3}$ This is higher than the maximum yield to maturity at which the Spanish government has issued debt since 2008 (6.97 percent for a 10-year bond issued on November 11, 2011) and is higher than the yield to maturity at which any European government issued government debt since 2008 with one exception: the Italian government issued a 7-year bond at a yield to maturity of 10.96 percent on December 13, 2012 (see Trebesch and Wright, 2013). In the simulations, the minimum issuance price for long-term debt is binding in only 0.007 percent of the periods.

As in Chatterjee and Eyigungor (2012), we assume a quadratic loss function for income during a default episode $\phi(y)=\max \left\{d_{0} y+d_{1} y^{2}, 0\right\}$. They show that this function allows the equilibrium default model to match the behavior of the spread in the data by affecting the sensitivity of the cost of defaulting to the domestic income shock, and through that, the sensitivity of bond prices to debt levels. Aguiar and Gopinath (2006) discuss how a cost of defaulting that is more sensitive to aggregate income shocks diminishes the sensitivity of the interest rate spread to the debt level, which reduces the marginal cost of debt issuances and, in turn, induces the government to issue debt at higher spread levels.

The rate of decay in long-term bonds $(1-\delta)$ and the two parameters that define the income cost of defaulting are calibrated to match: (i) the average duration of government debt, (ii) the level of government debt, and (iii) the average long-term interest rate spread. We use data from Spain from 2008 to 2013 to calculate those moments. ${ }^{4}$ We choose that

\footnotetext{
${ }^{3}$ The annualized yield to maturity of a long-term bond is calculated as

$$
i_{L}=\left(\frac{1}{q_{L}}+1-\delta\right)^{4}-1 .
$$

${ }^{4}$ We use the Macaulay definition of duration, which with the coupon structure of long-term bonds assumed in this paper is calculated as
} 
sample period because the interest rate spread of Spanish government debt was around zero between 1999 and 2007 (and even negative in some periods) and that prior to the beginning of the Euro, the Spanish government issued debt denominated in local currency.

\section{Results}

Following Hatchondo et al. (2010), we solve the model numerically using value function iteration and interpolation. We solve for the equilibrium of a finite-horizon economy with a number of periods large enough to make the value functions and bond prices for the first and second periods sufficiently close. We then use the first-period equilibrium functions as the infinite-horizon-economy equilibrium functions. We provide more details of the computation in the Appendix.

First, we discuss government borrowing in the baseline model. Secondly, we show that the baseline model can account for salient features of business cycle dynamics in Spain (and in other economies with sovereign risk). Thirdly, we discuss the effects of debt dilution on the level of indebtedness, sovereign risk, the term structure of sovereign risk, the optimal maturity of sovereign debt, consumption volatility, and welfare. Fourthly, we show that gains from eliminating dilution can be obtained with covenants that would be easier to implement. Fifthly, we compare the allocation without dilution with the allocation that the government could attain if it could trade a full range of one-period Arrow-Debreu claims contingent on local income realizations. Sixthly, we compare the allocation without dilution with the

$$
D=\frac{\frac{b_{L}+b_{S}}{1+i}+b_{L} \sum_{t=2}^{\infty} t \frac{(1-\delta)^{t-1}}{(1+i)^{t}}}{\frac{b_{L}+b_{S}}{1+i}+b_{L} \sum_{t=2}^{\infty} \frac{(1-\delta)^{t-1}}{(1+i)^{t}}}
$$

where $i$ denotes the constant yield to maturity of long-term bonds. 
allocation that the government could attain with non-defaultable debt.

\subsection{Government borrowing}

Figure 1 illustrates how the yield the government pays when it borrows changes with the level of borrowing, domestic income, and foreign consumption growth. As expected, the yield increases with the borrowing level (more borrowing implies higher default risk), decreases with domestic income (higher domestic income implies the expectation of higher future income, and thus lower default risk), and increases when foreign consumption growth is expected to be higher (and thus foreigners are less eager to lend).

Figure 1 also illustrates how issuing long-term debt instead of short-term debt reduces the government's exposure to rollover risk. Each period, the government only needs to pay a fraction of its long-term debt, and the shock to foreign consumption growth affects the long-term yield less than the short-term yield (this is because of the mean reversion in the foreigners' consumption growth process and is consistent with the lower volatility of long-term yields relative to the short-term yields of U.S. government debt).

If long-term debt reduces the government's exposure to rollover risk, why does the government issue short-term debt? By issuing short term debt the government limits the scope for future debt dilution and thus lowers the yield it has to pay when it borrows. To illustrate this, equations (16) and (17) present the first-order conditions for the issuance of long-term and short-term debt, respectively (first-order conditions assume differentiability, that the constraint on the long-term bond price is not binding in the current or next period, and that it is optimal to repay the debt in the current period; we do not make these assumptions when we find numerical solutions): 


$$
\begin{aligned}
& u^{\prime}(c)\left[q_{L}\left(b_{S}^{\prime}, b_{L}^{\prime}, y, g^{*}\right)+\frac{\partial q_{L}\left(b_{S}^{\prime}, b_{L}^{\prime}, y, g^{*}\right)}{\partial b_{L}^{\prime}}\left[b_{L}^{\prime}-(1-\delta) b_{L}\right]+\frac{\partial q_{S}\left(b_{S}^{\prime}, b_{L}^{\prime}, y, g^{*}\right)}{\partial b_{L}^{\prime}} b_{S}^{\prime}\right]= \\
& \beta E_{y^{\prime}, g^{* \prime}}\left[\left(1-d^{\prime}\right) u^{\prime}\left(c^{\prime}\right)\left(1+(1-\delta) q_{L}^{\prime}\right)-d^{\prime} \frac{\partial \hat{V}^{D}\left(b_{S}^{\prime}, b_{L}^{\prime}, y^{\prime}, g^{* \prime}\right)}{\partial b_{L}^{\prime}} \mid y, g^{*}\right], \\
& u^{\prime}(c)\left[q_{S}\left(b_{S}^{\prime}, b_{L}^{\prime}, y, g^{*}\right)+\frac{\partial q_{L}\left(b_{S}^{\prime}, b_{L}^{\prime}, y, g^{*}\right)}{\partial b_{S}^{\prime}}\left[b_{L}^{\prime}-(1-\delta) b_{L}\right]+\frac{\partial q_{S}\left(b_{S}^{\prime}, b_{L}^{\prime}, y, g^{*}\right)}{\partial b_{S}^{\prime}} b_{S}^{\prime}\right]= \\
& \beta E_{y^{\prime}, g^{* \prime}}\left[\left(1-d^{\prime}\right) u^{\prime}\left(c^{\prime}\right)-d^{\prime} \frac{\partial \hat{V}^{D}\left(b_{S}^{\prime}, b_{L}^{\prime}, y^{\prime}, g^{* \prime}\right)}{\partial b_{S}^{\prime}} \mid y, g^{*}\right],
\end{aligned}
$$

where $d^{\prime}$ and $q_{L}^{\prime}$ are defined as in equations (5) and (7), and $c^{\prime}$ denotes consumption in the next period when the government in the next period follows the defaulting rule $\hat{d}$, and borrowing rules $\hat{b}_{S}$ and $\hat{b}_{L}$. The left-hand sides of these equations show that when the government issues an additional bond the increase in consumption financed by this issuance is lower than the price of the bond. This occurs because the additional bond issuance lowers the price at which the government sells other bonds (as captured by the second and third terms of the left-hand side of the equations). Thus, the government's concern about the price of the bonds it issues in the current period limits the number of bonds issued. By choosing shorter-term debt, the government commits to rolling over a larger share of its debt in the future. Therefore, the government commits to being more concerned about the price of debt in the future and to a lower level of future debt dilution. We later show that the government would indeed benefit from committing to lowering future debt dilution and that doing so through debt covenants would allow the government to extend the maturity of its debt. 


\subsection{Simulations of the baseline model}

Table 2 reports moments in the data and in our simulations. Given that there has not been a sovereign default in Spain in recent years, we report results for simulated sample paths without defaults. We generate 1,000 sample paths of 300 periods each. We take the last 74 periods (quarters) of samples without a default in the last 100 periods. We focus on samples of 74 periods because we compare the artificial data generated by the model with Spanish data from the first quarter of 1995 to the second quarter of 2013 (except for interest rate spreads and debt statistics). ${ }^{5}$

The moments reported in Table 2 are chosen to illustrate the ability of the model to replicate distinctive business cycle properties of economies with sovereign risk. ${ }^{6}$ The table shows that the baseline model with dilution approximates well the moments used as targets and it is broadly consistent with non-targeted moments in the data: consumption is more volatile than income, the trade balance is countercyclical and the average spread for shortterm debt is lower than the average spread for long-term debt. As a ratio of income volatility, consumption volatility is higher in our simulations than in the sample period we look at. However consumption volatility in our simulations is lower than that reported by Alvarez-

\footnotetext{
${ }^{5}$ We compute the spread in the simulations as the extra yield to maturity delivered by a defaultable bond over the yield to maturity of a default-free bond with the same structure of coupon payments. We report the annualized spread

$$
R_{j}^{s}=\left(\frac{1+i_{j}}{1+r_{j}}\right)^{4}-1, \text { for } j=S, L,
$$

where $R_{S}^{s}\left(R_{L}^{s}\right)$ denotes the spread of a short-term (long-term) bond, $i_{S}=1 / q_{S}-1$ denotes the yield to maturity of a defaultable short-term bond, $r_{S}=1 / E_{g^{* \prime}}\left[M\left(g^{*}, g^{*^{\prime}}\right) \mid g^{*}\right]-1$ denotes the yield to maturity of a default-free short-term bond, $i_{L}$ denotes the yield to maturity of a long-term defaultable bond (computed as in footnote 3 ), and $r_{L}$ denotes the yield to maturity of a long-term default-free bond.

${ }^{6}$ In terms of consumption volatility and the co-movement between the trade balance and GDP, business cycle dynamics in Spain resemble more those of emerging economies than those of advanced small open economies (see Aguiar and Gopinath, 2007).
} 
Parra et al. (2013) for Spain between the first quarter of 2000 and the third quarter of 2008. The model not only mimics the average duration of debt (targeted) but also approximates well a standard measure of debt maturity: the fraction of total debt obligations that mature within the next year (non-targeted).

Estimating the default probability in the data is elusive. Model simulations display 3 defaults per 100 years, which is in the ballpark of existing estimations. For instance, this is the frequency targeted by Aguiar and Gopinath (2006) based on the data reported by Reinhart et al. (2003). Since the period with positive interest rate spread in Spain that we use is relatively short and the spread is clearly non-stationary in that period, we chose not to compare the co-movement between the spread and other macroeconomic variables. ${ }^{7}$ Next, we measure the effects of debt dilution in the baseline economy by comparing the baseline simulation results with the simulation results for the economy without dilution.

\subsection{Dilution and the level of debt}

Table 3 shows that the mean debt-to-income ratio is 5.2 percent lower in the economy without dilution. In order to shed light on how eliminating debt dilution affects the level of debt, it is useful to show how eliminating dilution affects the first-order conditions. The first-order conditions in the economy without dilution are given by:

$$
\begin{aligned}
& u^{\prime}\left(c^{\text {No dil }}\right)\left[q_{L}^{\text {No dil }}\left(b_{S}^{\prime}, b_{L}^{\prime}, y, g^{*}\right)+\frac{\partial q_{L}^{\text {No dil }}\left(b_{S}^{\prime}, b_{L}^{\prime}, y, g^{*}\right)}{\partial b_{L}^{\prime}} b_{L}^{\prime}+\frac{\partial q_{S}^{\text {No dil }}\left(b_{S}^{\prime}, b_{L}^{\prime}, y, g^{*}\right)}{\partial b_{L}^{\prime}} b_{S}^{\prime}\right]= \\
& -\beta E_{y^{\prime}, g^{* \prime}}\left[\left(1-d^{\prime}, \text { No dil }\right) \frac{\partial \hat{V}^{R, \text { No dil }}\left(b_{S}^{\prime}, b_{L}^{\prime}, y^{\prime}, g^{* \prime}\right)}{\partial b_{L}^{\prime}}+d^{\prime}, \text { No dil } \frac{\partial \hat{V}^{D, \text { No dil }}\left(b_{S}^{\prime}, b_{L}^{\prime}, y^{\prime}, g^{* \prime}\right)}{\partial b_{L}^{\prime}} \mid y, g^{*}\right](19)
\end{aligned}
$$

\footnotetext{
${ }^{7}$ In our simulations the spread is countercyclical, as is often observed in economies facing sovereign risk (see Neumeyer and Perri, 2005 and Uribe and Yue, 2006).
} 


$$
\begin{aligned}
& u^{\prime}\left(c^{\text {No dil }}\right)\left[q_{S}^{\text {No dil }}\left(b_{S}^{\prime}, b_{L}^{\prime}, y, g^{*}\right)+\frac{\partial q_{L}^{\text {No dil }}\left(b_{S}^{\prime}, b_{L}^{\prime}, y, g^{*}\right)}{\partial b_{S}^{\prime}} b_{L}^{\prime}+\frac{\partial q_{S}^{\text {No dil }}\left(b_{S}^{\prime}, b_{L}^{\prime}, y, g^{*}\right)}{\partial b_{S}^{\prime}} b_{S}^{\prime}\right]= \\
& -\beta E_{y^{\prime}, g^{* \prime}}\left[\left(1-d^{\prime}, \text { No dil }\right) \frac{\partial \hat{V}^{R, \text { No dil }}\left(b_{S}^{\prime}, b_{L}^{\prime}, y^{\prime}, g^{* \prime}\right)}{\partial b_{S}^{\prime}}+d^{\prime}, \text { No dil } \frac{\partial \hat{V}^{D, \text { No dil }}\left(b_{S}^{\prime}, b_{L}^{\prime}, y^{\prime}, g^{* \prime}\right)}{\partial b_{S}^{\prime}} \mid y, g^{*}\right](20)
\end{aligned}
$$

where the super-index "No dil" is used to denote functions in the economy without dilution (as before, first-order conditions assume that the government chooses to borrow in the current period and abstract from the constraint on long-term bond prices).

The comparison of the equations (16)-(17) and equations (19)-(20) shows how in the model without dilution, the borrowing cost is higher, which leads to lower debt levels. In the left-hand sides of equations (16)-(17), the government only internalizes as a cost the negative effect that bond issuances have on the value of the long-term debt it issues in the current period: $b_{L}^{\prime}-(1-\delta) b_{L}$. The negative effect bond issuances have on the value of the long-term debt issued in previous periods $\left((1-\delta) b_{L}\right)$ does not constitute a cost for the government. In contrast, the left-hand sides of equations (19)-(20) show that in the model without dilution, when the government issues debt, it internalizes the dilution of the value of all long-term debt: $b_{L}^{\prime}$. This is so because the government must compensate holders of long-term debt issued in previous periods for debt dilution.

\subsection{Dilution and sovereign risk}

Table 3 shows that debt dilution accounts for 78 percent of the default frequency in the simulations of the baseline model: the number of defaults per 100 years decreases from 2.78 in the baseline to 0.61 in the model without debt dilution. Debt dilution also accounts for 71 
percent (47 percent) of the long-term-debt (short-term-debt) spread paid by the sovereign. ${ }^{8}$

Sovereign risk is lower without dilution not only because debt levels are lower, but also because the default risk implied by any debt level is lower without dilution. This is illustrated in Figure 2. For the same debt level, future debt levels (and thus future default probabilities) are expected to be lower without dilution, which means that yields will be lower without dilution. In particular, for low debt levels, the probability of a default in the next period is negligible, and the yield to maturity of a long-term bond with the covenant that eliminates dilution is the same as that of a default-free bond with the same promised payments. In contrast, in the economy with dilution the yield is higher than that of a default-free bond, even for low debt levels. This is the case because lenders anticipate that, even if the debt level chosen by the government in the current period is low and implies a low default probability for the next period, the value of their bonds could be diluted by future debt issuances that will increase the probability of a default. With the covenant that eliminates dilution, the bond values are high for debt levels that command a negligible default probability for the next period. This is because the covenant precludes dilution by future issuances. Thus, Figure 2 illustrates how dilution eliminates valuable borrowing opportunities for the government.

\footnotetext{
${ }^{8}$ The yield $i_{L}$ of a long-term bond in the no-dilution economy satisfies:$$
q_{L}^{\mathrm{No} \operatorname{dil}}\left(b_{S}{ }^{\prime}, b_{L}{ }^{\prime}, y, g^{*}\right)=\frac{1}{1+i_{L}} E_{y^{\prime}, g^{* \prime}}\left[1+\mathcal{C}\left(b_{L}^{\prime}, y^{\prime}, g^{*,}, b_{S}{ }^{\prime \prime}, b_{L}{ }^{\prime \prime}\right)+(1-\delta) q_{L}^{\mathrm{No} \operatorname{dil}}\left(b_{S}{ }^{\prime \prime}, b_{L}{ }^{\prime \prime}, y^{\prime}, g^{* \prime}\right) \mid y, g^{*}\right],
$$

where $b_{S}{ }^{\prime \prime}=\hat{b}_{S}^{\text {No dil }}\left(b_{S}{ }^{\prime}, b_{L}{ }^{\prime}, y^{\prime}, g^{* \prime}\right), b_{L}{ }^{\prime \prime}=\hat{b}_{L}^{\text {No dil }}\left(b_{S}{ }^{\prime}, b_{L}{ }^{\prime}, y^{\prime}, g^{* \prime}\right)$, and the superindex "No dil" is used to denote functions in the economy without dilution. The annualized interest rate spread is calculated as in equation (18).
} 


\subsection{Dilution and the term structure of sovereign risk}

Table 3 shows that while the average spread for long-term debt is three times the average spread for short-term debt in the baseline simulations with dilution, the average spread is slightly higher for long-term debt in the simulations without dilution. The government can always issue short-term debt at a very low spread in good times (i.e., when a default is not imminent). In contrast, in the baseline economy, even in good times the government has to compensate those who buy long-term debt for the expectation of future debt dilution. Eliminating dilution brings the spread paid for long-term bond issuances closer to that paid for short-term issuances.

\subsection{Dilution and the optimal maturity of sovereign debt}

Table 3 shows that eliminating dilution increases significantly the average debt maturity chosen by the government. Comparing the simulations of the models with and without dilution, the average debt duration increases by almost two years and the share of shortterm debt declines 42 percent. As explained in Subsection 5.1, increasing the duration of debt lowers rollover risk. However, in the benchmark economy, the government shortens the maturity of its debt issuances in order to commit to lower levels of debt dilution in the future. Eliminating debt dilution through debt covenants allows the government to reduce its exposure to rollover risk by increasing the average maturity of debt issuances.

\subsection{Dilution and consumption volatility}

Eliminating dilution also leads to an increase in consumption volatility (Table 3 ). This occurs because in the economy without dilution, the government borrows more than in the 
benchmark for higher domestic income levels, and borrows less for lower domestic income levels, as illustrated in Figure 3. When domestic income is lower, the government is more reluctant to issue debt because the change in bond prices implied by debt issuances is larger (equivalently, Figure 2 shows that bond yields are more sensitive to debt levels when domestic income is lower). This is exacerbated in the economy without dilution because the government must compensate holders of debt issued in previous periods for changes in bond prices caused by current borrowing.

The previous discussion shows that eliminating dilution presents a trade-off between reducing the frequency of defaults and increasing consumption volatility. The next subsection shows that eliminating dilutions produces welfare gains, which suggests that the first effect dominates in terms of welfare.

\subsection{Welfare gains from eliminating dilution}

We measure welfare gains as the constant proportional change in consumption that would leave a consumer indifferent between living in the benchmark economy (with dilution) and moving to an economy without dilution. The solid line in Figure 4 presents these welfare gains for the case in which there is no initial debt. ${ }^{9}$ Figure 4 shows that there are positive welfare gains from eliminating dilution. This indicates that gains from reducing the frequency of defaults (which are not optimal from an ex-ante perspective) are larger than the cost of

\footnotetext{
${ }^{9}$ These welfare gains are given by

$$
\left[\frac{\hat{V}^{\mathrm{No} \operatorname{dil}}\left(0,0, y, g^{*}\right)}{\hat{V}^{\operatorname{Dil}}\left(0,0, y, g^{*}\right)}\right]^{\left(\frac{1}{1-\gamma}\right)}-1
$$

where the superindex "Dil" refers to functions in the economy with dilution and the superindex "No dil" refers to functions in the economy without dilution.
} 
increasing the volatility of consumption.

\subsection{Welfare and bondholders' capital gains}

Since there is no unique way of comparing debt stocks with and without the covenant that eliminates dilution, the previous subsection presents welfare gains from eliminating dilution for the case without initial debt. This subsection discusses welfare gains with positive initial debt, assuming that dilution is eradicated when all bonds without the covenant that eliminates dilution are swaped for bonds with this covenant. Studying indebted governments is clearly the empirically relevant case. Furthermore, eliminating dilution would increase the market value of bonds (as illustrated by the lower sovereign yields for the economy without dilution presented in Figure 2), producing capital gains for debt holders. As is standard in the sovereign default literature, we assume that the government does not benefit from bondholders' capital gains. This assumption is clearly extreme. While the baseline default model assumes that all bondholders are foreigners, in reality a large fraction (and often a majority) of sovereign debt is held by domestic agents. What would be the gains from eliminating dilution if the government could benefit from the appreciation in the value of previously issued debt? In order to shed light on this question, the dotted line in Figure 4 presents welfare gains under the assumption that the government captures bondholders' capital gains through a debt restructuring that does not reduce the value of bondholders' debt claims. Thus, the analysis in this subsection can also be interpreted as a discussion of the benefits of introducing debt covenants that eliminate dilution in the context of a debt restructuring.

The dotted line in Figure 4 assumes the government extends a take-it-or-leave-it debt 
buyback offer promising that the covenants that eliminate dilution will be introduced only if the offer is accepted. Creditors would accept any government offer that would not lower the market value of their debt claims. Thus, the government offers creditors the opportunity to buy back previously issued bonds at the price that would have been observed if dilution was never eliminated. That price is lower than the price at which the government would be able to issue debt after eliminating dilution (as illustrated by the yields depicted in Figure 2). ${ }^{10}$ Figure 4 shows that welfare gains from eliminating dilution when the government enters the period with a debt portfolio equal to the mean debt portfolio in the simulations and captures bondholders' capital gains may be greater than one percentage point.

One could also argue that our measures of welfare gains from eliminating dilution are low because there is no production in our setup and, therefore, we cannot capture the effects of the level and volatility of interest rates on aggregate income (Mendoza and Yue, 2012; Sosa-Padilla, 2012). Several studies find evidence of significant effects of the level of interest rates on aggregate productivity (through the allocation of factors of production), and of a significant role of interest rate fluctuations in the amplification of shocks (Mendoza and Yue, 2012; Neumeyer and Perri, 2005; Uribe and Yue, 2006).

\subsection{Bondholders' risk aversion}

Table 4 shows that the effects of eliminating dilution are robust to changing the bondholders' risk aversion. For risk aversion parameter values between 5 and 59 (the benchmark

\footnotetext{
${ }^{10}$ In the period of the exchange, the budget constraint under repayment reads $c=y-b_{S}-b_{L}\left[1+(1-\delta) q_{L}^{\text {Dil }}\left(\hat{b}_{S}^{\text {Dil }}\left(b_{S}, b_{L}, y, g^{*}\right), \hat{b}_{L}^{\text {Dil }}\left(b_{S}, b_{L}, y, g^{*}\right), y, g^{*}\right)\right]+q_{L}^{\text {No dil }}\left(b_{S^{\prime}}{ }^{\prime}, b_{L}{ }^{\prime}, y, g^{*}\right) b_{L}{ }^{\prime}+q_{S}^{\text {No dil }}\left(b_{S}{ }^{\prime}, b_{L}{ }^{\prime}, y, g^{*}\right) b_{S}{ }^{\prime}$.

Equation (12) presents the budget constraint for all future periods in which the government is not in default.
} 
value), eliminating debt dilution reduces the default frequency between 78 and 81 percent and increases the average debt duration between 1.3 and 1.8 years. Furthermore, a previous version of this paper (Hatchondo et al., 2012) presents robustness exercises to the bondholders' risk aversion, the cost of defaulting, and an external source of rollover risk, and shows that debt dilution accounts for between 77 percent and 86 percent of the default frequency in the benchmark simulations. ${ }^{11}$

\subsection{Debt-threshold covenant}

Implementing the debt covenant that eliminates dilution would require knowledge of the counterfactual price of long-term debt that would have been observed in the absence of debt issuances. Thus, it would require knowledge of the mapping from fundamentals onto the price of long-term debt (equation 11). We next study the effects of imposing simpler debt covenants that mitigate the dilution problem but do not require knowledge of that mapping.

One important characteristic of the covenant that eliminates dilution is that it penalizes the government for borrowing and thus induces lower debt levels. We capture this characteristic by imposing a bond covenant that promises to compensate creditors at the beginning of each period when the debt level is higher than a certain threshold. To study the effects of introducing such covenant, we define the sovereign debt level as $b_{S}+\frac{b_{L}}{\delta+r}$, and the threshold debt level that triggers compensations as $\bar{b}$. Thus, the compensation in the new covenant is given by

\footnotetext{
${ }^{11}$ This previous version presents a model with exogenous debt maturity (that thus cannot be shortened to mitigate dilution), zero recovery for debt in default, and a calibration targeting data from Argentina and thus featuring a much higher default frequency and a much lower level of debt.
} 


$$
\mathcal{C}_{b}\left(b_{S}+\frac{b_{L}}{\delta+r}\right)=\psi \operatorname{Max}\left\{b_{S}+\frac{b_{L}}{\delta+r}-\bar{b}, 0\right\}
$$

Formally, we study the model without dilution presented in Section 3 but with the covenant payment given by equation (21) instead of equation (11).

We search for the ex-ante optimal values of $(\psi, \bar{b})$. We find that the optimal values are $\psi=0.3$ and $\bar{b}=2$. Thus, this covenant forces the government to make payments when it issues debt and has a debt level $b_{S}+\frac{b_{L}}{\delta+r}$ higher than 50 percent of the mean annual income. Henceforth, we refer to the model where compensations to creditors are determined with these optimal values as the model with the debt-threshold covenant.

Table 5 presents simulation results for the economy with the debt-threshold covenant. This covenant lowers both the default probability and consumption volatility and, thus, produces welfare gains. However, these gains are lower than those obtained from eliminating dilution. On the one hand, the default probability is higher with the debt-threshold covenant than in the economy without dilution. This occurs even though the debt level is lower with the debt-threshold covenant. On the other hand, consumption volatility is lower with the debt-threshold covenant than in the economy without dilution. As discussed in subsection 5.8, in this model economy, gains from lowering the default frequency are larger than the cost of increasing consumption volatility. Since the covenant that eliminates dilution produces a lower default frequency (and higher debt levels) at the expense of a higher consumption volatility, it produces larger welfare gains than the debt-threshold covenant.

The main difference between the debt-threshold covenant and the covenant that eliminates dilution is that the latter tends to penalize borrowing more when income is lower (in 
which case the price of long-term debt is more sensitive to the borrowing level). Therefore, the covenant that eliminates dilution increases consumption volatility. Furthermore, since this covenant induces the government to choose lower debt levels when income is lower and thus the default probability is higher, it leads to a lower default frequency than the debt-threshold covenant, even with a higher average debt level.

Not surprisingly, the average present value of coupon payments in the simulations is slightly below the level "targeted" by the covenant, $\bar{b}$, and very close to this level at 49.3 percent. This indicates that this debt covenant could strengthen a government's commitment to fiscal rules, which often target debt levels (Hatchondo et al., 2011).

\subsection{Price-threshold covenant}

A second important characteristic of the covenant that eliminates dilution is that it compensates creditors for a decline in bond prices. We introduce next a covenant that compensates creditors for a decline in bond prices, and does not depend on the counterfactual bond price that would be observed in the absence of debt issuances in the current period (as the covenant that eliminates dilution does).

We assume that if the government issues debt, it has to pay, to the holder of each longterm bond it issued in the past, the difference between a constant reference price $\bar{q}_{L}$ and the post-issuance market price for long-term bonds $q_{L}\left(b_{S}^{\prime}, b_{L}^{\prime}, y, g^{*}\right)$. Thus, the compensation promised in the covenants of long-term bonds is 
$\mathcal{C}_{q}\left(b_{L}, y, g^{*}, b_{S}^{\prime}, b_{L}^{\prime}\right)= \begin{cases}\operatorname{Max}\left\{\bar{q}_{L}-q_{L}\left(b_{S}^{\prime}, b_{L}^{\prime}, y, g^{*}\right), 0\right\} & \text { if } b_{L}^{\prime}>(1-\delta) b_{L} \text { or } b_{S}^{\prime}>0, \text { and } \\ 0 & \text { otherwise. }\end{cases}$

Formally, we study the model without dilution presented in Section 3 but with the covenant payment given by equation (22) instead of by equation (11).

We search for the optimal value of $\bar{q}_{L}$ and find that this value is 2.5 percent lower than the average price of a default-free long-term bond without covenants. Henceforth, we refer to the model where compensations to creditors determined with the optimal $\bar{q}_{L}$ as the model with the price-threshold covenant.

Table 5 presents simulation results for the economy with the price-threshold covenant. This covenant generates a lower default frequency than the debt-threshold covenant, but at the expense of a higher consumption volatility. Furthermore, compared with the covenant that eliminates dilution, the price-threshold covenant produces a slightly lower default frequency and a considerably higher consumption volatility. This is the case because the covenant that eliminates dilution only transfers resources to lenders due to declines in bond prices caused by bond issuances. In summary, our findings indicate that simple covenants could produce welfare gains by (i) reducing the frequency of default (more effectively when targeting a bond price), and (ii) reducing the consumption volatility (more effectively when targeting a level of debt). 


\subsection{Optimal income-contingent debt}

We next study model economies in which we relax important constraints of the baseline environment. This allows us to show that while mitigating debt dilution brings significant gains, these gains are smaller than the distortions in the baseline economy. This subsection discusses the gains from introducing optimal state contingency into debt instruments. In particular, we focus on debt claims that are contingent on the realization of domestic income.

We assume that the government can issue one-period Arrow-Debreu securities that pay off conditionally on the domestic income realization in the next period. That is, the government chooses how much it promises to pay in the next period for each domestic income realization $y^{\prime}$ (payments can be negative). We also assume that the government can only promise payments for which it will choose not to default. This assumption simplifies the analysis, and we show that it is unlikely that it has significant quantitative effects on the results. The costs of defaulting are the same as in the benchmark economy, and as in the rest of the paper, we focus on Markov Perfect Equilibria. We solve for the equilibrium using the baseline parameter values presented in Table 1.

The beginning-of-the-period value function in this economy is given by

$$
\begin{aligned}
& W\left(b, y, g^{*}\right)=\max _{b^{\prime}\left(y^{\prime}\right)}\left\{u(c)+\beta E_{y^{\prime}, g^{* \prime}}\left[W\left(b^{\prime}\left(y^{\prime}\right), y^{\prime}, g^{* \prime}\right) \mid y, g^{*}\right]\right\}, \\
& \text { subject to } \\
& c=y-b+E_{g^{* \prime}}\left[M\left(g^{*}, g^{* \prime}\right) \mid g^{*}\right] \int b^{\prime}\left(y^{\prime}\right) F\left(d y^{\prime} \mid y\right) \text { and } \\
& b^{\prime}\left(y^{\prime}\right) \leq \bar{b}\left(y^{\prime}\right),
\end{aligned}
$$

where $b^{\prime}\left(y^{\prime}\right)$ denotes the payments promised by the government in the next period conditional on an income realization $y^{\prime}$ in the next period, $F$ denotes the cumulative distribution 
function for domestic income $y$, and the borrowing constraint is given by

$$
\bar{b}\left(y^{\prime}\right)=\sup \left\{\tilde{b}: W\left(\tilde{b}, y^{\prime}, g^{*}\right) \geq W^{D}\left(\tilde{b}, y^{\prime}, g^{*}\right) \quad \forall g^{*}\right\}
$$

where the continuation value under default $W^{D}$ satisfies

$$
\begin{aligned}
& W^{D}\left(b, y, g^{*}\right)=u(c)+\beta E_{y^{\prime}, g^{* \prime}}\left[(1-\xi) W^{D}\left(b^{\prime}, y^{\prime}, g^{* \prime}\right)+\xi W\left(\alpha b^{\prime}, y^{\prime}, g^{* \prime}\right) \mid y, g^{*}\right] \\
& \text { subject to } \\
& c=y-\phi(y), \text { and } \\
& b^{\prime}=b(1+r) .
\end{aligned}
$$

We solve for the functions $W$ and $W^{D}$ that satisfy functional equations (23) and (25).

Table 6 presents simulation results in the benchmark economy, in the economy without dilution, and in the economy with debt payments indexed to domestic income. The table shows that welfare gains from moving to the economy without dilution represent 37 percent of the gains from moving to the economy with optimal income-contingent debt. As one would expect, the economy with optimal income-contingent debt displays higher borrowing levels and lower consumption volatility than the benchmark. With optimal income-contingent debt, the government chooses to promise lower payments for periods of lower income, and thus lowers the volatility of consumption. Furthermore, debt claims contingent on domestic income allow the government to increase the average borrowing level by promising to pay more when income and thus the cost of defaulting are higher.

Simulation results with optimal income-contingent debt are in sharp contrast with the ones obtained for the economy without debt dilution. In that economy, (covenant) payments 
are also contingent to the level of domestic income (equation 11). However, the government does not choose optimally the income-contingency of debt instruments. In particular, the covenant that eliminates dilution induces the government to borrow less when income is low, increasing the volatility of consumption.

Figure 5 shows that assuming that the government cannot issue debt levels for which it would choose to default (equation 24) is unlikely to have a significant effect on the results. The equilibrium functions $W$ and $W^{D}$ are not very sensitive to the realization of the lenders' consumption growth rate. Thus, it seems very unlikely that a default would be triggered by a shock to foreign consumption growth. Therefore, the maximum debt level (for a given level of domestic income in the next period) that would imply a positive repayment probability is very close to the maximum debt level that implies repayment with certainty.

\subsection{Non-defaultable debt}

This subsection discusses gains from introducing (one-period) non-defaultable debt. Formally, we solve for a recursive competitive equilibrium characterized by a value function $V$ and borrowing rule $\hat{b}$ such that:

(a) The value function $V$ solves the functional equation: 


$$
\begin{aligned}
& V\left(b, y, g^{*}\right)=\max _{b^{\prime}}\left\{u(c)+\beta E_{y^{\prime}, g^{* \prime}}\left[V\left(b^{\prime}, y^{\prime}, g^{* \prime}\right) \mid y, g^{*}\right]\right\} \\
& \text { subject to } \\
& c=y-b+q\left(g^{*}\right) b^{\prime} \\
& b^{\prime} \leq \bar{b} \\
& q\left(g^{*}\right)=E_{g^{* \prime}}\left[M\left(g^{*}, g^{* \prime}\right) \mid g^{*}\right] .
\end{aligned}
$$

(b) The borrowing rule $\hat{b}$ attains the maximum of equation (26) for all $\left(b, y, g^{*}\right)$.

We solve for the equilibrium using the parameter values presented in Table 1. We assume that $\bar{b}=60 E[y]$. This bound is close to the natural borrowing limit for the income grid used to solve the model.

Table 7 shows that while welfare gains from eliminating dilution could be significant, welfare gains from directly committing to not defaulting could be almost 30 times larger. As expected, the government exploits the laxer borrowing constraint to carry a significantly higher debt level. As illustrated by the average debt level in Table 7, the debt limit is often binding, leaving little room for debt to be used to smooth consumption (the ratio of standard deviations in the table is for the log of the variables, and the level of consumption is considerably lower than the level of income resulting in a larger volatility for the log of consumption).

Large welfare gains obtained from higher debt levels depend crucially on our assumption of a benevolent government representing the interests of an impatient representative agent. The borrower's high impatience, which is typically assumed in the sovereign default literature, is justified as a reduced form for political conflicts (Amador, 2012; Azzimonti, 
2011; Cuadra and Sapriza, 2008). In a framework with political conflict, enhancing the government's ability to borrow may reduce welfare.

\section{Conclusions}

We showed that debt dilution could account for a significant share of sovereign default risk. We solved a model of sovereign defaultable debt in which debt instruments feature a covenant that eliminates debt dilution by making the value of long-term bonds independent of future borrowing decisions. We measured the effects of debt dilution by comparing the simulations of this model with those of the baseline model without this debt covenant. Using Spanish data to parameterize the model, we found that the default frequency in simulations of the model without dilution represents only 22 percent of the default frequency in simulations of the baseline model with dilution. We also showed that without dilution, the optimal duration of sovereign debt increases by almost two years. Eliminating dilution also increases consumption volatility (borrowing when income is low is relatively more expensive in the economy without dilution) but nevertheless produces welfare gains because it lowers the frequency of defaults.

The debt covenant that eliminates dilution mandates payments that depend on the counterfactual price that would have been observed in the absence of current-period borrowing: each time the government borrows, it has to compensate the holders of long-term debt issued in previous periods by paying the difference between the observed long-term bond price and this counterfactual price. This makes this covenant difficult to implement.

We showed that gains from eliminating dilution could be obtained with debt covenants 
that do not depend on a counterfactual bond price and thus are easier to implement. We studied two covenants. A price-threshold covenant transfers resources to bondholders when the bond price at which the government borrows is below a threshold. A debt-threshold covenant transfers resources to bondholders when the level of indebtedness is above a threshold. We showed that the price-threshold covenant is more effective in reducing default risk (by inducing debt reductions when domestic income and thus the cost of defaulting are low). The debt-threshold covenant is more effective in reducing consumption volatility (by allowing for relatively more borrowing when domestic income is low). These debt covenants could help enforcing fiscal rules. 


\section{A Numerical Algorithm}

The algorithm iterates on two value functions, $V^{R}$ and $V^{D}$, and four price functions- $q_{L}$, $q_{L}^{D}, q_{S}$, and $q_{S}^{D}$ - until convergence is attained. We approximate $V^{R}$ and $V^{D}$ using linear interpolation for $y$ and bi-dimensional tensor-product spline interpolation for $b_{S}$ and $b_{L}$, using the routines BS2IN and BS2VL from the IMSL library in Fortran. We discretize the stochastic process for $g^{*}$ following Tauchen (1986). We use grids of evenly distributed points. We use 20 grid points for $y, 25$ grid points for $b_{S}, 25$ grid points for $b_{L}$, and 5 grid points for $g^{*}$.

The expectations $E_{y, g^{*}}\left[f\left(b_{S}^{\prime}, b_{L}^{\prime}, y^{\prime}, g^{* \prime} \mid y, g^{*}\right)\right]$ for $f=\hat{V}\left(b_{S}^{\prime}, b_{L}^{\prime}, y^{\prime}, g^{* \prime}\right), V^{D}\left(b_{S}^{\prime}, b_{L}^{\prime}, y^{\prime}, g^{* \prime}\right)$, $q_{L}\left(\hat{b}_{S}\left(b_{S}^{\prime}, b_{L}^{\prime}, y^{\prime}, g^{* \prime}\right), \hat{b}_{L}\left(b_{S}^{\prime}, b_{L}^{\prime}, y^{\prime}, g^{* \prime}\right), y^{\prime}, g^{* \prime}\right), q_{L}^{D}\left(b_{S}^{\prime}, b_{L}^{\prime}, y^{\prime}, g^{* \prime}\right)$, and $q_{S}^{D}\left(b_{S}^{\prime}, b_{L}^{\prime}, y^{\prime}, g^{* \prime}\right)$ are calculated using 50 Gauss-Legendre quadrature points over $y^{\prime}$ and the 5 grid points over $g^{* \prime}{ }^{12}$

The algorithm used to solve for the equilibrium with interpolation works as follows. First, we specify initial guesses for $V^{R}, V^{D}, q_{L}$, and $q_{S}$. We use as initial guesses the continuation values at the last period of the finite-horizon version of the model, i.e., for values of $\left(b_{S}, b_{L}, y, g^{*}\right)$ on the grid for asset levels and endowment shocks, $q_{L}=q_{S}=0$,

$$
\begin{gathered}
V^{R}\left(b_{S}, b_{L}, y, g^{*}\right)=u\left(y-b_{L}-b_{S}\right), \text { and } \\
V^{D}\left(b_{S}, b_{L}, y, g^{*}\right)=u(y-\phi(y)) .
\end{gathered}
$$

\footnotetext{
${ }^{12}$ In order to speed up the code, we use a version of parameterized expectations to approximate the expectations for those functions. That is, at the beginning of each iteration, we compute those expectations for a grid of 50 values for $b_{S}, 50$ values for $b_{L}$, and the same grid points for $y$ and $g^{*}$, where the problem is solved. We use a bi-dimensional tensor product spline interpolation over $b_{S}$ and $b_{L}$ for solving the optimization problem and for updating $V^{D}$.
} 
Second, we solve the optimization problem defined in (10) for each point on the grid. In order to solve for the optimum, we first find a candidate value for the optimal borrowing level using a global search procedure: we first search over 20 points for $b_{S}^{\prime}$. For each of these values, we search over 15 points for $b_{L}^{\prime}$ and find the $b_{L}^{\prime}$ that attains the maximum value of the objective function defined in (10). That value is used as an initial guess in a one-dimensional optimization routine UVMIF from the IMSL library. That conditional optimization routine is defined over $b_{L}$ for a fixed $b_{S}$. We then use the value of $b_{S}^{\prime}$ that attains the maximum value (and its corresponding optimal value for $b_{L}^{\prime}$ ) as the initial guess in a two-dimensional optimization routine that uses the Powell algorithm. We update $V^{D}$, $q_{S}$, and $q_{L}$ using functional equations (4)-(8).

If the maximum distance between the updated values for $V^{R}, V^{D}, q_{S}$, and $q_{L}$ and their previous ones is below $10^{-6}$, a solution has been found. If it is not, we repeat the optimization exercise using the new continuation values $V^{R}$ and $V^{D}$, and bond prices $q_{S}$, and $q_{L}$.

Using a two-dimensional tensor-product spline to interpolate over $b_{S}^{\prime}$ and $b_{L}^{\prime}$ works best when the function $V^{R}$ is differentiable over $b_{S}$ and $b_{L}$. This need not be the case in the current setup because of the constraint that the long-term bond price cannot be lower than $\underline{q}_{L}$. However, we find that this constraint is binding only for state realizations in which the government would have chosen to default. For instance, Figure 6 depicts the value function for a low domestic income realization. The non-differentiability introduced by the default decision is significantly milder than in models without positive recovery. 


\section{References}

Aguiar, M. and Gopinath, G. (2006). 'Defaultable debt, interest rates and the current account'. Journal of International Economics, volume 69, 64-83.

Aguiar, M. and Gopinath, G. (2007). 'Emerging markets business cycles: the cycle is the trend'. Journal of Political Economy, volume 115, no. 1, 69-102.

Alvarez-Parra, F., Brandao-Marques, L., and Toledo, M. (2013). 'Durable goods, financial frictions, and business cycles in emerging economies'. Journal of Monetary Economics, volume $60(6), 720-736$.

Amador, M. (2012). 'Sovereign Debt and the Tragedy of Commons'. Manuscript, Stanford University.

Arellano, C. (2008). 'Default Risk and Income Fluctuations in Emerging Economies'. American Economic Review, volume 98(3), 690-712.

Arellano, C. and Ramanarayanan, A. (2012). 'Default and the Maturity Structure in Sovereign Bonds'. Journal of Political Economy, volume 120, no. 2, 187-232.

Asquith, P., Beatty, A., and Weber, J. (2005). 'Performance pricing in bank debt contracts'. Journal of Accounting and Economics, volume 40, 101128.

Azzimonti, M. (2011). 'Barriers to Investment in Polarized Societies'. American Economic Review, volume 101(5), 2182-2204.

Benjamin, D. and Wright, M. L. J. (2008). 'Recovery Before Redemption? A Theory of Delays in Sovereign Debt Renegotiations'. Manuscript. 
Bi, R. (2006). 'Debt Dilution and the Maturity Structure of Sovereign Bonds'. Manuscript, University of Maryland.

Bianchi, J. (2011). 'Overborrowing and Systemic Externalities in the Business Cycle'. American Economic Review, volume 101(7), 3400-3426.

Bizer, D. S. and DeMarzo, P. (1992). 'Sequential Banking'. Journal of Political Economy, volume $100,41-61$.

Bolton, P. and Jeanne, O. (2009). 'Structuring and Restructuring Sovereign Debt: The Role of Seniority'. Review of Economic Studies, volume 76, 879-902.

Borensztein, E., Chamon, M., Jeanne, O., Mauro, P., and Zettelmeyer, J. (2004). 'Sovereign Debt Structure for Crisis Prevention'. IMF occasional paper 237.

Borensztein, E. and Panizza, U. (2009). 'The Costs of Sovereign Default'. IMF Staff Papers, volume 56(4), 683-741.

Carey, M., Prowse, S., Rea, J., and Udell, G. (1993). 'he Economics of the Private Placement Market'. Board of Governors of the Federal Reserve System.

Chamon, M. and Mauro, P. (2006). 'Pricing growth-indexed bonds'. Journal of Banking 86 Finance, volume 30, 3349-3366.

Chatterjee, S. and Eyigungor, B. (2012). 'Maturity, Indebtedness and Default Risk'. American Economic Review, volume 102(6), 2674-2699.

Chatterjee, S. and Eyigungor, B. (2013). 'Debt Dilution and Seniority in a Model of Defaultable Sovereign Debt'. Federal Reserve Bank of Philadelphia Working Paper No. 13-30. 
Cruces, J. J. and Trebesch, C. (2013). 'Sovereign Defaults: The Price of Haircuts'. American Economic Journal: Macroeconomics, volume 5(3), 85-117.

Cuadra, G. and Sapriza, H. (2008). 'Sovereign default, interest rates and political uncertainty in emerging markets'. Journal of International Economics, volume 76, 7888.

Dias, D. A. and Richmond, C. (2009). 'Duration of Capital Market Exclusion: An Empirical Investigation'. Working Paper, UCLA.

Eaton, J. and Gersovitz, M. (1981). 'Debt with potential repudiation: theoretical and empirical analysis'. Review of Economic Studies, volume 48, 289-309.

Epstein, L. G. and Zin, S. E. (1989). 'Substitution, Risk Aversion, and the Temporal Behavior of Consumption and Asset Returns: A Theoretical Framework'. Econometrica, volume 57(4), 937-969.

García-Cicco, J., Pancrazi, R., and Uribe, M. (2010). 'Real Business Cycles in Emerging Countries?' American Economic Review, volume 100, 2510-2531.

Gelos, G., Sahay, R., and Sandleris, G. (2011). 'Sovereign Borrowing by Developing Countries: What Determines Market Access?' Journal of International Economics, volume 83, $243-254$.

Hatchondo, J. C. and Martinez, L. (2009). 'Long-duration bonds and sovereign defaults'. Journal of International Economics, volume 79, 117-125.

Hatchondo, J. C. and Martinez, L. (2013). 'Sudden Stops, Time Inconsistency, and the Duration of Sovereign Debt'. International Economic Journal, volume 27 (1), 217-228. 
Hatchondo, J. C., Martinez, L., and Roch, F. (2011). 'Fiscal rules and the sovereign default premium'. Mimeo, University of Chicago.

Hatchondo, J. C., Martinez, L., and Sapriza, H. (2010). 'Quantitative properties of sovereign default models: solution methods matter'. Review of Economic Dynamics, volume 13, no. 4, 919-933.

Hatchondo, J. C., Martinez, L., and Sosa Padilla, C. (2012). 'Debt dilution and sovereign default risk'. Federal Reserve Bank of Richmond Working Paper 10-08R.

Hatchondo, J. C., Martinez, L., and Sosa Padilla, C. (2014). 'Voluntary Sovereign Debt Exchanges'. Journal of Monetary Economics, volume 61, 32-50.

Kletzer, K. M. (1984). 'Asymmetries of Information and LDC Borrowing with Sovereign Risk'. The Economic Journal, volume 94, 287-307.

Levy Yeyati, E. and Panizza, U. (2011). 'The elusive costs of sovereign defaults'. Journal of Development Economics, volume 94, 95-105.

Mendoza, E. and Yue, V. (2012). 'A General Equilibrium Model of Sovereign Default and Business Cycles'. The Quarterly Journal of Economics, volume 127(2), 889-946.

Neumeyer, P. and Perri, F. (2005). 'Business cycles in emerging economies: the role of interest rates'. Journal of Monetary Economics, volume 52, 345-380.

Piazzesi, M. and Schneider, M. (2007). 'Equilibrium Yield Curves'. NBER Macroeconomics Annual, pages 389-472. Vol. 21, ed. Daron Acemoglu, Kenneth Rogoff, and Michael Woodford, Cambridge, MA: MIT Press. 
Reinhart, C., Rogoff, K. S., and Savastano, M. A. (2003). 'Debt Intolerance'. Brookings Papers on Economic Activity, pages 1-74.

Rodgers, C. (1965). 'The corporate trust indenture project'. Business Lawyer, volume 20, $551-571$.

Schaechter, A., Kinda, T., Budina, N., and Weber, A. (2012). 'Fiscal Rules in Response to the CrisisToward the Next-Generation Rules. A New Dataset'. IMF Working Paper $12 / 187$.

Smith, C. W. and Warner, J. B. (1979). 'On Financial Contracting: An Analysis of Bond Covenants'. Journal of Financial Economics, volume 7, 117-161.

Sosa-Padilla, C. (2012). 'Sovereign Defaults and Banking Crises'. Working Paper. McMaster University.

Tauchen, G. (1986). 'Finite state markov-chain approximations to univariate and vector autoregressions'. Economics Letters, volume 20 (2), 177-181.

Trebesch, C. and Wright, M. L. J. (2013). 'A Default Measure of Sovereign Default'. Mimeo.

Uribe, M. and Yue, V. (2006). 'Country spreads and emerging countries: Who drives whom?' Journal of International Economics, volume 69, 6-36.

Weil, P. (1989). 'The Equity Premium Puzzle and the Risk-Free Rate Puzzle'. Journal of Monetary Economics, volume 24(3), 401-421. 
TABLE 1: Parameter Values

\begin{tabular}{|c|c|c|c|}
\hline Domestic income autocorrelation coefficient & $\rho$ & 0.97 & Spain 1960Q1-2013Q1 \\
\hline Standard deviation of domestic innovations & $\sigma_{\epsilon}$ & $1.04 \%$ & Spain 1960Q1-2013Q1 \\
\hline Mean log income & $\mu_{y}$ & $(-1 / 2) \sigma_{\epsilon}^{2}$ & Mean income level = 1 \\
\hline Borrower's risk aversion & $\gamma$ & 2 & Prior literature \\
\hline Borrower's discount factor & $\beta$ & 0.98 & Prior literature \\
\hline Bondholders' risk aversion & $\gamma^{*}$ & 59 & Piazzesi and Schneider (2007) \\
\hline Bondholders' discount factor & $\beta^{*}$ & 0.99614 & Mean real rate $=1 \%$ \\
\hline Bondholders' consumption autocorr. coefficient & $\rho^{*}$ & 0.329 & U.S. private consumption \\
\hline Bondholders' std. dev. of consumption innovations & $\sigma_{\epsilon}^{*}$ & $0.4722 \%$ & U.S. private consumption \\
\hline Bondholders' mean consumption growth & $\mu_{g^{*}}$ & $0.8 \%$ & U.S. private consumption \\
\hline Duration of defaults & $\xi$ & 0.083 & Dias and Richmond (2009) \\
\hline Recovery rate of debt in default & $\alpha$ & 0.63 & Cruces and Trebesch (2013) \\
\hline Minimum issuance price for long-term debt & $\underline{q}$ & 0.693 & Trebesch and Wright (2013) \\
\hline Duration of long-term bond & $\delta$ & 0.0225 & Calibrated to fit targets \\
\hline Income loss while in default & $d_{0}$ & -0.698 & Calibrated to fit targets \\
\hline Income loss while in default & $d_{1}$ & 0.8 & Calibrated to fit targets \\
\hline
\end{tabular}

Note.- The source for Spanish GDP is Banco de España. The source for U.S. consumption is the Bureau of Economic Analysis. 
TABLE 2: Business CYCLE STATISTICS

\begin{tabular}{lcc}
\hline \hline & Spain & $\begin{array}{c}\text { With } \\
\text { dilution }\end{array}$ \\
\hline Moments targeted in the calibration & & \\
Debt / mean annual income (in \%) & 61.8 & 61.8 \\
Debt duration (years) & 6.00 & 5.95 \\
Spread of long-term debt (in \%) & 2.04 & 2.10 \\
\hline Non-targeted moments & & \\
Debt obligations within 1 year/ Total debt (in \%) & 21.1 & 23.2 \\
Spread of short-term debt (in \%) & 0.86 & 0.73 \\
$\sigma(c) / \sigma(y)$ & 1.15 & 1.50 \\
$\rho(T B / y, y)$ & -0.72 & -0.73 \\
\hline
\end{tabular}

Note.- The standard deviation of a variable $x$ is denoted by $\sigma(x)$. The coefficient of correlation between $x$ and $z$ is denoted by $\rho(x, z)$. The second column is computed using data from Spain. We use data from 1995 to 2013 for aggregate private consumption, trade balance, and GDP. The logarithm of private consumption $(c)$, the logarithm of income $(y)$, and the trade balance to income ratio $(T B)$ were de-trended using the Hodrick-Prescott filter with a smoothing parameter of 1600 . We report deviations from the trend. The source for consumption, income, and trade balance is Haver Analytics. We use data from 2008 to 2013 for the interest rate spread and debt statistics. The short-term spread was computed using the yield of 3-month government bonds in Spain and Germany. The long-term spread was computed using the yield to maturity of 8-year government bonds in Spain and Germany. The source for the data on bond yields is Bloomberg. The source for government debt and the ratio of debt obligations maturing within the next year is the Government Statistics Database of the European Central Bank. The source for government debt duration is JP Morgan. Column 3 reports the mean of the value of each moment in 1,000 simulation samples. We take the last 74 periods (quarters) of samples in which no default occurs in the last 100 periods. The level of long-term debt in the simulations is calculated as the present value of future payment obligations discounted at the average short-term risk-free rate, i.e., $b_{L}(\delta+r)^{-1}$. 
TABle 3: Business Cycle Statistics in the Baseline Economy and in the Economy Without Dilution

\begin{tabular}{lcc}
\hline \hline & With & Without \\
& dilution & dilution \\
\hline Debt / mean annual income (in \%) & 61.8 & 58.6 \\
Debt duration (years) & 5.95 & 7.70 \\
Debt obligations within 1 year/ Total debt (in \%) & 23.0 & 13.4 \\
Spread of long-term debt (in \%) & 2.10 & 0.60 \\
Spread of short-term debt (in \%) & 0.73 & 0.39 \\
$\sigma(c) / \sigma(y)$ & 1.50 & 2.07 \\
$\rho(T B / y, y)$ & -0.73 & -0.69 \\
Defaults per 100 years & 2.78 & 0.61 \\
\hline
\end{tabular}


TABle 4: Effects of Eliminating Dilution for Different Lenders' CoeffiCIEnts of Relative Risk Aversion

\begin{tabular}{lccccccc}
\hline \hline Lenders' risk aversion & 59 (benchmark) & 50 & 40 & 30 & 20 & 10 & 5 \\
\hline Decline of default frequency & 0.78 & 0.81 & 0.81 & 0.80 & 0.80 & 0.79 & 0.79 \\
Increase of debt duration (years) & 1.76 & 1.35 & 1.30 & 1.33 & 1.34 & 1.45 & 1.55 \\
\hline
\end{tabular}


TABle 5: Simulation Results for Different Debt Covenants

\begin{tabular}{lcccc}
\hline \hline & With & Without & Debt & Price \\
& dilution & dilution & threshold & threshold \\
\hline Debt / mean annual income (in \%) & 61.8 & 58.6 & 50.0 & 56.3 \\
Debt duration (years) & 5.95 & 7.70 & 7.48 & 7.55 \\
Debt obligations within 1 year/ Total debt (in \%) & 23.0 & 13.4 & 12.3 & 12.2 \\
Spread of long-term debt (in \%) & 2.10 & 0.60 & 0.84 & 0.88 \\
Spread of short-term debt (in \%) & 0.73 & 0.39 & 0.40 & 0.32 \\
$\sigma(c) / \sigma(y)$ & 1.50 & 2.07 & 1.06 & 3.01 \\
$\rho(T B / y, y)$ & -0.73 & -0.69 & -0.51 & -0.69 \\
$\begin{array}{l}\text { Defaults per } 100 \text { years } \\
\text { Welfare gain }(\% \text { of cons.) }\end{array}$ & 2.78 & 0.61 & 1.68 & 0.49 \\
\hline
\end{tabular}

NotE.- The welfare gain corresponds to the average gain for the case of zero debt. 
TABLE 6: Optimal Income-Contingent Debt

\begin{tabular}{lccc}
\hline \hline & $\begin{array}{c}\text { With } \\
\text { dilution }\end{array}$ & $\begin{array}{c}\text { Without } \\
\text { dilution }\end{array}$ & $\begin{array}{c}\text { State-contingent } \\
\text { claims }\end{array}$ \\
\hline Debt / mean annual income (in \%) & 61.8 & 58.6 & 75.0 \\
$\sigma(c) / \sigma(y)$ & 1.50 & 2.07 & 0.67 \\
$\rho(T B / y, y)$ & -0.73 & -0.69 & 0.81 \\
Defaults per 100 years & 2.78 & 0.61 & 0 \\
Welfare gain (\% of cons.) & & 0.41 & 1.12 \\
\hline
\end{tabular}

Note.- Moments for the economy with debt contingent on domestic income correspond to averages over the last 74 periods of each sample path. Welfare gains are ex-ante gains for the case of zero initial debt. 
TABLE 7: Non-defaultable Debt

\begin{tabular}{lccc}
\hline \hline & $\begin{array}{c}\text { With } \\
\text { dilution }\end{array}$ & $\begin{array}{r}\text { Without } \\
\text { dilution }\end{array}$ & $\begin{array}{c}\text { Without } \\
\text { defaults }\end{array}$ \\
\hline Debt / mean annual income (in \%) & 61.8 & 58.6 & 1,485 \\
$\sigma(c) / \sigma(y)$ & 1.50 & 2.07 & 3.29 \\
$\rho(T B / y, y)$ & -0.73 & -0.69 & -0.46 \\
Defaults per 100 years & 2.78 & 0.61 & 0 \\
Welfare gain $(\%$ of cons.) & & 0.41 & 11.41 \\
\hline
\end{tabular}

Note.- Moments in the economy without defaults correspond to averages over the last 74

periods of each sample path. Welfare gains are ex-ante gains for the case of zero initial debt. 
a

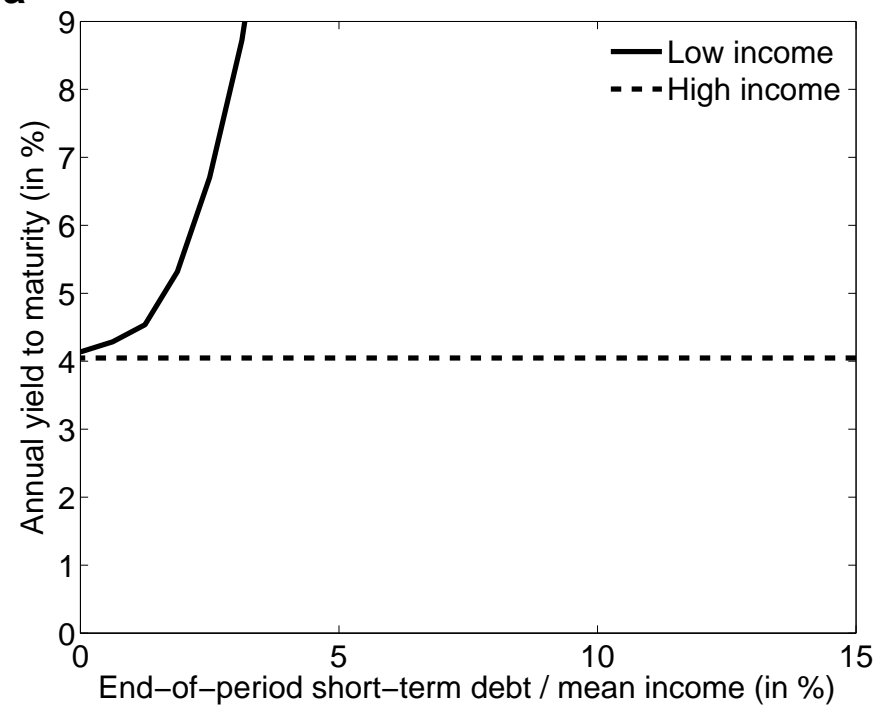

C

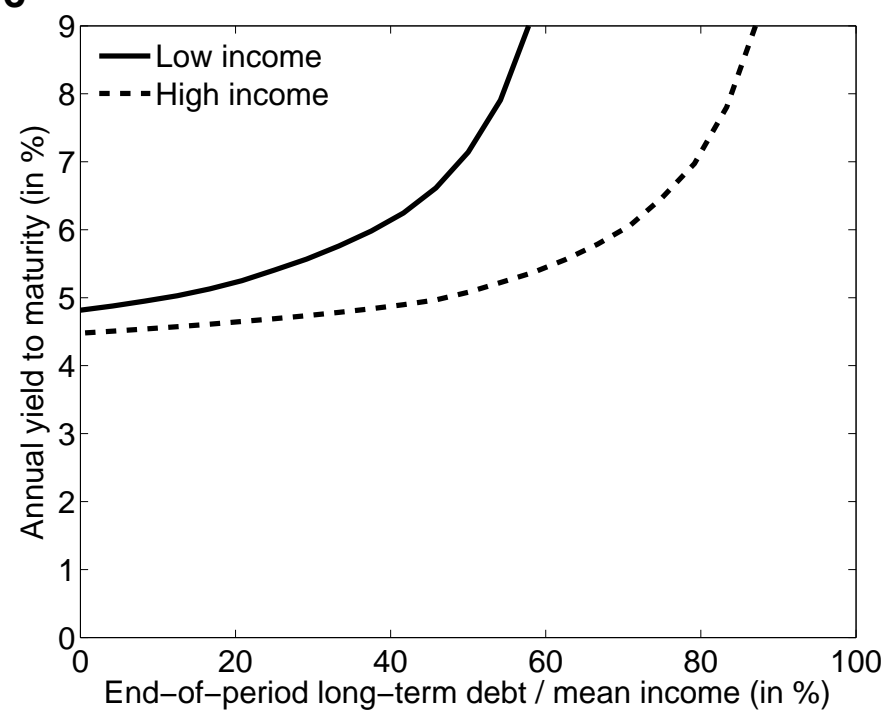

b

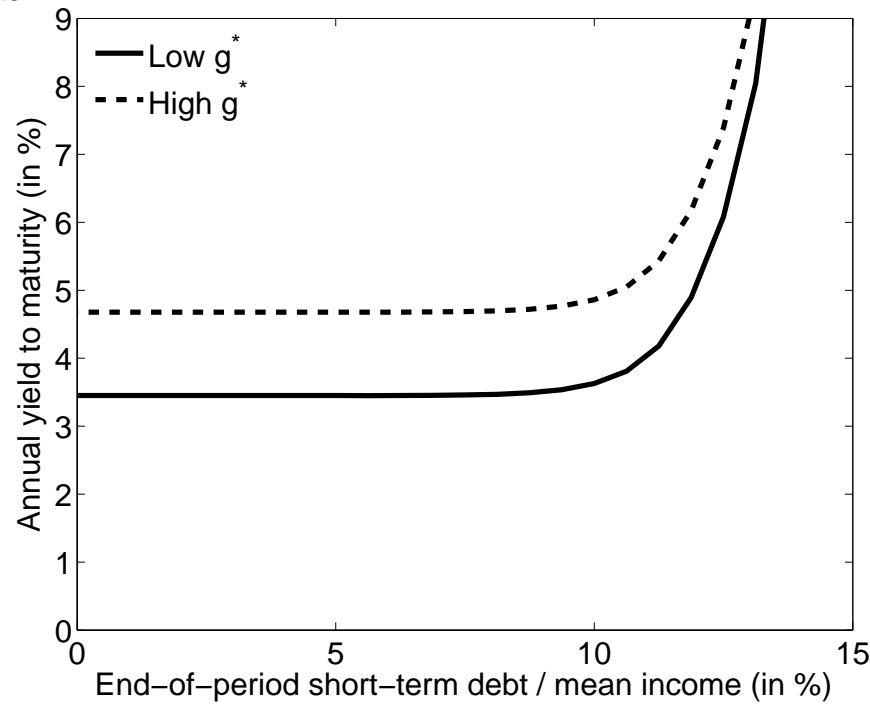

d

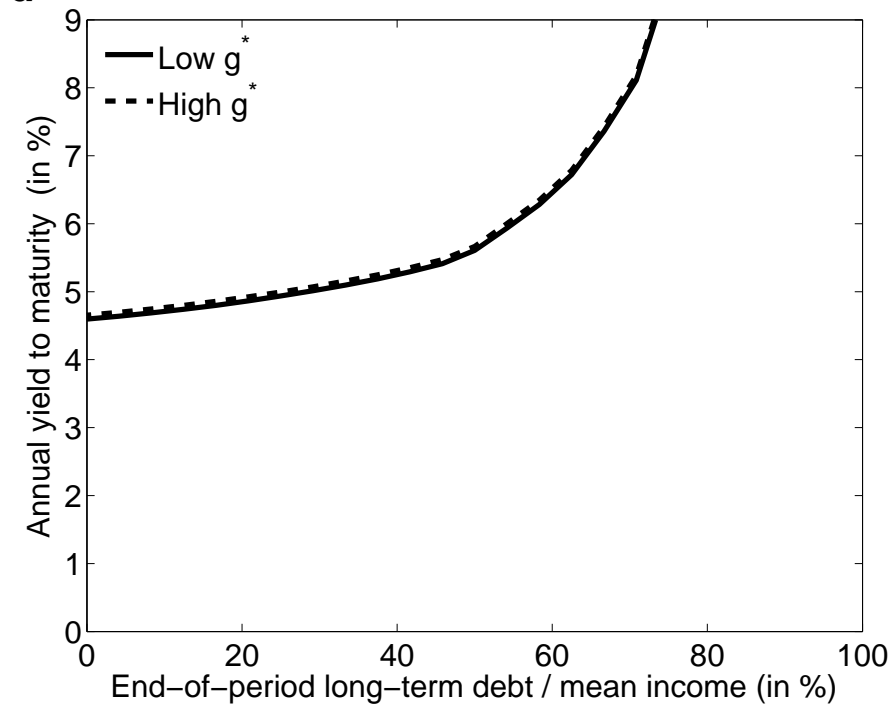

FIG. 1: Menus of combinations of yield to maturity and end-of-period debt levels from which the government can choose in the baseline economy. Left panels ( $a$ and $c$ ) assume $g^{*}=\mu_{g^{*}}$. Right panels ( $b$ and $d$ ) assume $\log (y)=\mu_{y}$. The low (high) value of $y$ in the left panels corresponds to a domestic income realization that is one standard deviation below (above) the unconditional mean. The low (high) value of $g^{*}$ in the right panels correspond to a bondholders' consumption growth realization that is one standard deviation below (above) the unconditional mean. The top panels ( $a$ and $b$ ) reflect the assumption that the government enters the period with a long-term debt level equal to the mean long-term debt level observed in the simulations and does not issue long-term debt in the current period. Bottom panels ( $c$ and $d$ ) assume that the government does not issue short-term debt in the current period. 


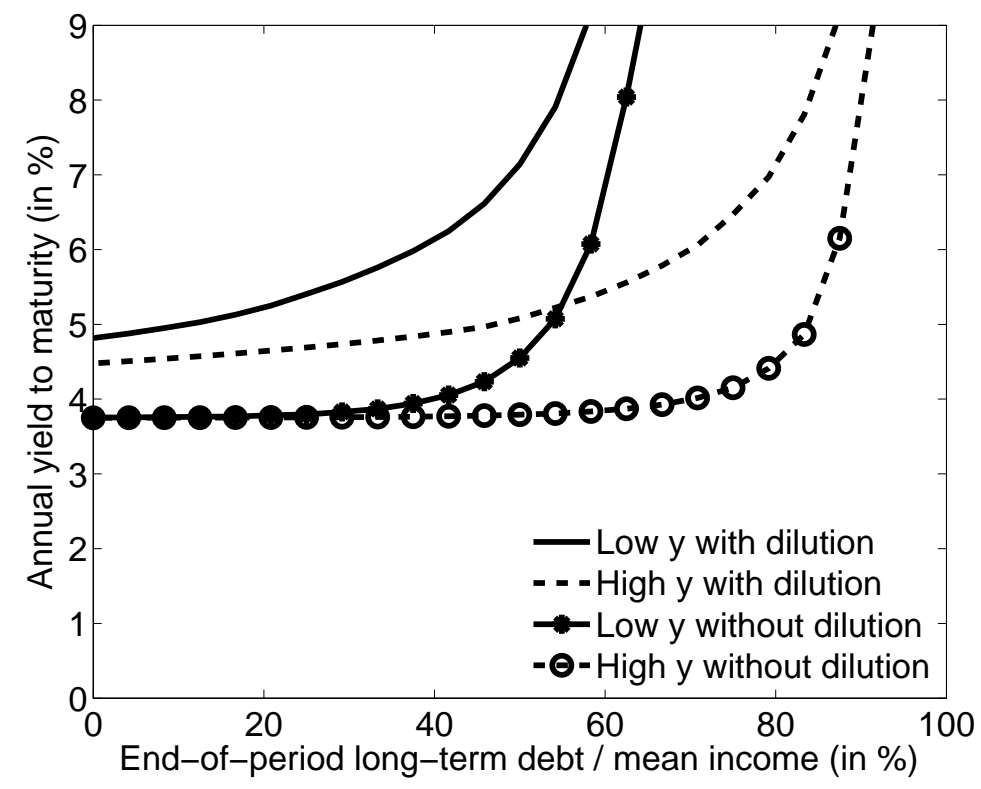

FIG. 2: Menu of combinations of yield to maturity of long-term debt $\left(i_{L}\right)$ and end-of-period longterm debt levels from which the government can choose in the baseline economy and in the economy without dilution. The graph assumes that the government does not issue short-term debt in the current period $\left(b_{S}^{\prime}=0\right)$ and that $g^{*}=\mu_{g^{*}}$. The low (high) value of $y$ corresponds to a domestic income realization that is one standard deviation below (above) the unconditional mean. 


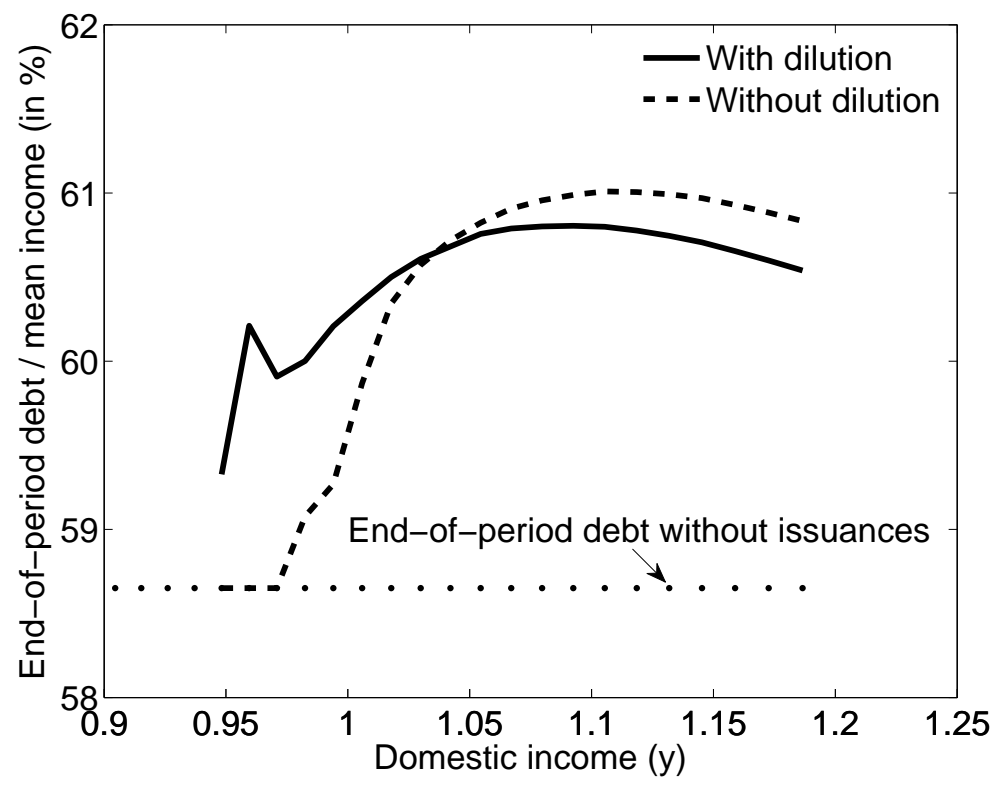

FiG. 3: End-of-period debt as a function of the domestic income realization. We plot domestic income realizations for which the government repays its debt in the current period. We assume $g^{*}=\mu_{g^{*}}$. The government starts the period without short-term debt and with a level of long-term debt equal to the mean level of total debt in the simulations. 


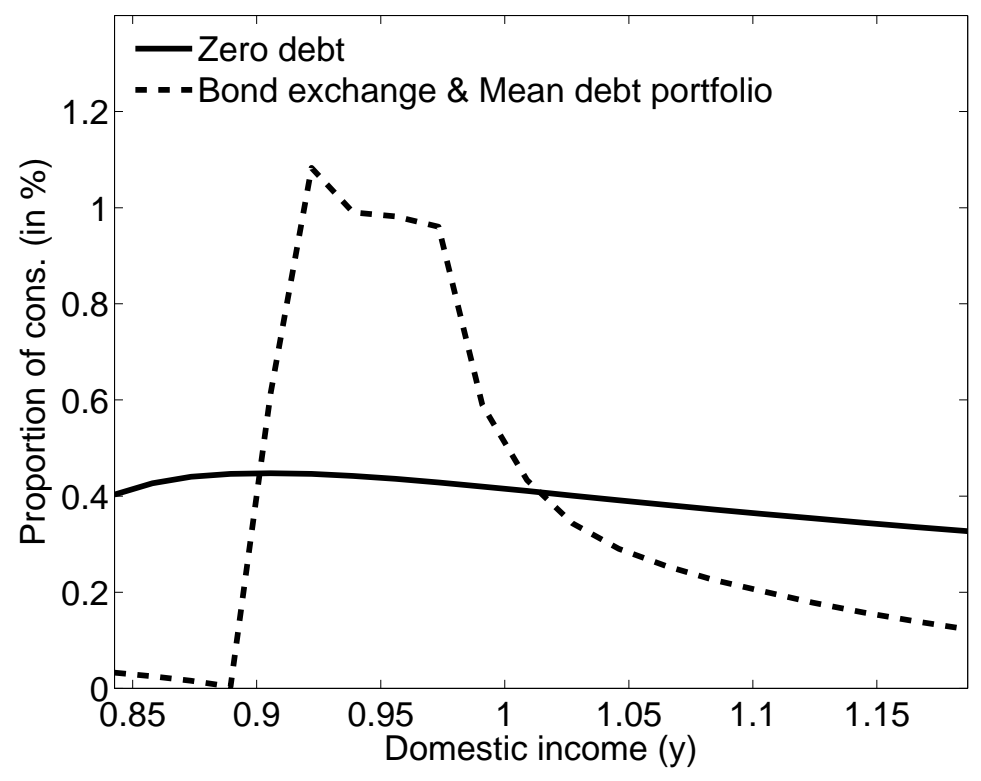

FIG. 4: Consumption compensation (in percentage terms) that makes domestic agents indifferent between living in an economy with or without dilution (a positive number means that domestic agents prefer the economy without dilution). We assume $g^{*}=\mu_{g^{*}}$. The dashed line assumes that the government buys back outstanding long-term bonds at the price that would have been observed in the baseline economy and then issues debt with the covenant that eliminates dilution. In that case, we assume the government enters the period with a debt portfolio equal to the average debt portfolio in the simulations of the baseline economy (with dilution). 
a

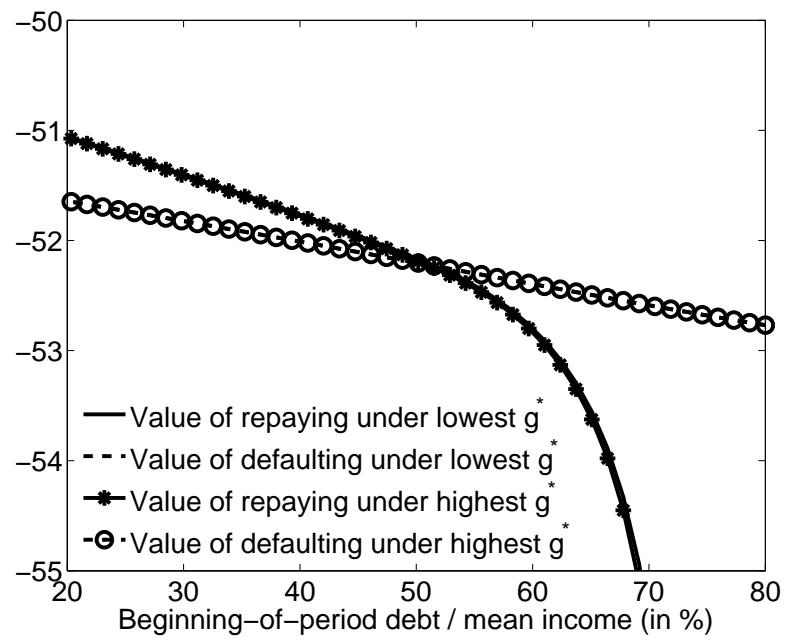

b

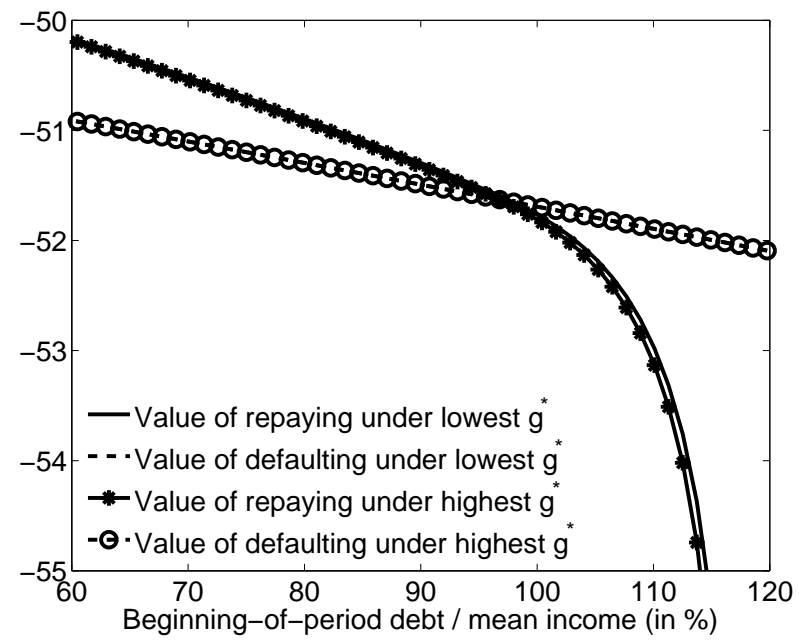

FIG. 5: Value functions of repayment $(W)$ and defaulting $\left(W^{D}\right)$ in the economy with incomecontingent debt. Panel $a(b)$ corresponds to a current domestic income realization that is one standard deviation below (above) the unconditional mean. The lowest (highest) value for $g^{*}$ corresponds to a foreign consumption growth rate that is 2 standard deviations below (above) the unconditional mean. The beginning of the period debt-to-income ratio was calculated as $b /(4 y)$. 


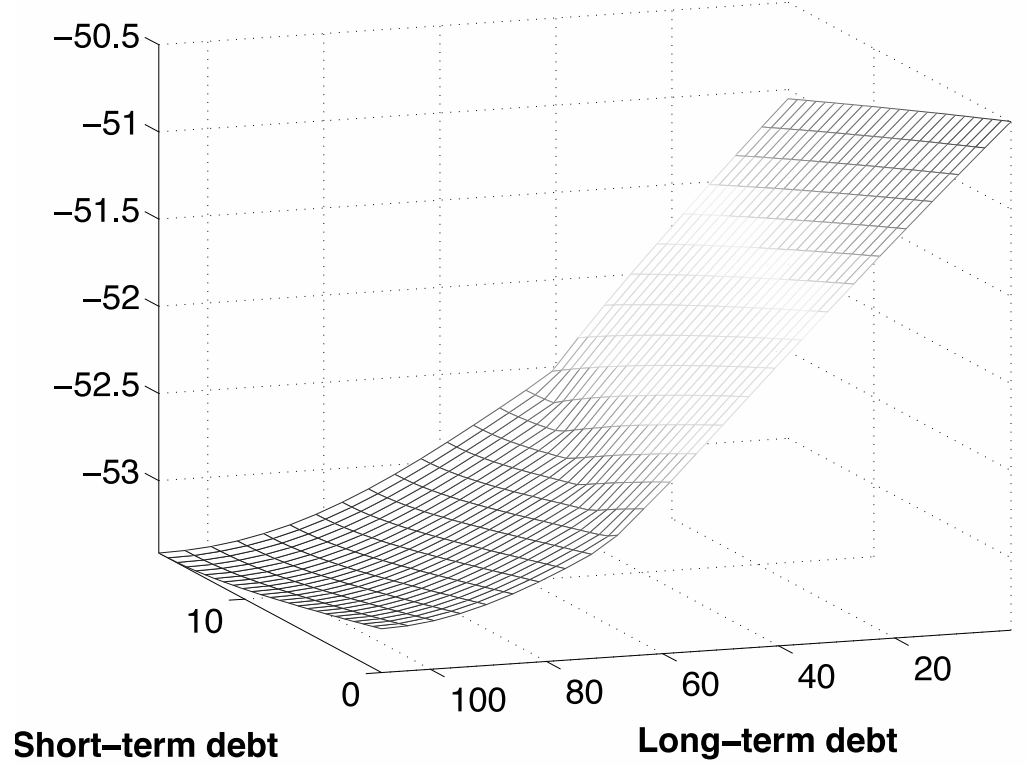

FIG. 6: Value function $V^{R}$ for a domestic income realization $y$ that is 2 standard deviations below the mean and $g^{*}=\mu_{g^{*}}$. 